\title{
Update on Rickettsioses in Slovakia
}

\author{
Z. SEKEYOVÁ ${ }^{1}$, C. SOCOLOVSCHI ${ }^{2}$, E. ŠPITALSKÁ ${ }^{1}$, E. KOCIANOVÁ ${ }^{1}$, V. BOLDIŠ ${ }^{3}$, M. QUEVEDO DIAZ ${ }^{1}$, \\ L. BERTHOVÁ ${ }^{1}$, M. BOHÁCSOVÁ ${ }^{1}$, J. VALÁRIKOVÁ ${ }^{1}$, P. EDOUARD FOURNIER ${ }^{2}$, D. RAOULT ${ }^{2}$
}

\begin{abstract}
${ }^{1}$ Institute of Virology, Slovak Academy of Sciences, Dúbravská cesta 9, 84505 Bratislava, Slovak Republic; ${ }^{2}$ Aix Marseille Université, URMITE, UM63, CNRS 7278, IRD 198, Inserm 1095, Marseille, France; ${ }^{3}$ HPL (Ltd) Medical Laboratories, Department of Parasitology, Bratislava, Slovak Republic
\end{abstract}

\begin{abstract}
Summary. - The reported incidence of vector-borne diseases including various cases of Rickettsioses in humans is increasing due to a combination of climatic and social factors, escalating the opportunities for contact between people and ticks, fleas or lice. Many of the emerging infectious diseases currently challenging human health in Europe are transmitted by ticks which normally feed on domestic or wild animals. Each Rickettsia spp. has one or several tick vectors, and their geographical distribution varies according to geographical conditions; e.g.; altitude or temperature, which is gradually changing due to a global warming. Evidence of Rickettsia spp. particularly of a newly discovered species is a strong indication that a great number of diseases may be caused by so far undetected or unrecognized organisms. Their diagnosis relies mostly on rare "spot like" cooperation of clinicians with scientists, the members of the working groups that are devoted to the scientific studies of the corresponding research areas. The clinical picture of the disease caused by rickettsiae varies significantly from flu like symptoms to severe fatal outcomes, reflecting the various factors, e.g. a variability of virulence of rickettsial species due to cell invasion, dissemination of rickettsiae, genomics, immune response of an infected organism, or a tricky impact of a treatment. Several major reviews on rickettsioses have been previously published, e.g. in 1997 (Raoult and Roux, 1997a), in 2005 (Parola et al., 2005), and in 2011 (Botelho-Nevers and Raoult, 2011). In this work we intend to present a short historical overview and to describe new trends in research studies of rickettsiology. The main focus will be on rickettsioses affecting Europe's population.
\end{abstract}

Keywords: rickettsiae; tick; lice; fleas; vector; Slovakia

\section{Contents:}

$\begin{array}{ll}\text { 1. } & \text { Inauguration of Rickettsiology } \\ \text { 2. } & \text { Taxonomy } \\ \text { 3. } & \text { Epidemiology } \\ \text { 4. } & \text { Vectors } \\ 4.1 & \text { Lice } \\ 4.2 & \text { Flea } \\ 4.3 & \text { Ticks } \\ 4.4 & \text { Other arthropod vectors } \\ \text { 5. } & \text { Morphology } \\ \text { 6. } & \text { Isolation } \\ \text { 7. } & \text { Genetic coding for intracellular activities } \\ \text { 8. } & \text { Detection } \\ \text { 9. } & \text { Pathology }\end{array}$

E-mail: viruseke@savba.sk; phone: +421-2-59302433.
10. Treatment

11. Rickettsiae in Slovakia

11.1 Arthropod vectors in Slovakia

11.2 SFG rickettsiae detected and/or isolated in Slovakia

11.2.1 Rickettsia slovaca

11.2.2 Rickettsia raoultii

11.2.3 Rickettsia monacensis

11.2.4 Rickettsia helvetica

11.2.5 Rickettsia conorii conorii

11.2.6 Rickettsia africae

11.2.7 Rickettsia species

\section{Inauguration of Rickettsiology}

Members of the family Rickettsiaceae have accompanied humans throughout the history of mankind. The founda- 
tion stone of rickettsiology was laid in ancient times. Currently this field of study has entered into incredibly large dimensions. Rickettsiology began with a concentrated effort of scientists to assign possible vectors (ticks, lice, flea, and mite) and reservoirs (mammals, humans, dogs, rabbits, birds, reptiles) of these microbial agents. They are an inevitable prerequisite for the spread and evolution of the variety of diseases they cause (Merhej and Raoult, 2011a; Renvoise et al., 2011). Rickettsia prowazekii (R. prowazekii), the agent of epidemic typhus, also known as louse-borne typhus is the oldest rickettsiosis and has caused more deaths than weapons during wartime. It was named in honour of Howard Taylor Ricketts and Stanislaus von Prowazek, who both died of typhus (da Rocha Lima, 1917). This microbe requires vertebrate hosts, human beings to maintain its life cycle and is transmitted by human body lice (Pediculus humanus humanus). Determination of the lice being a vector gained a Nobel Price for the man who discovered this, Dr. Charles Nicolle. Recently, an extra facet of its persistence in nature has been revealed as a natural reservoir of $R$. prowazekii: a North American squirrel (Glaucomys volans) in Virginia, USA, and thereafter in Florida and Maryland (Bozeman et al., 1975) as well as in ticks in Ethiopia and Mexico.

A second agent, Rickettsia typhi (R. typhi) causes murine or endemic typhus. This bacteria was proved to be transmitted mainly by rats flea Xenopsylla cheopis (Azad, 1990), but occasionally by other flea species or arthropod vectors, including cat fleas Ctenocephalides felis (Irons et al., 1944; Le Chuiton et al., 1935; Lepine and Lorando, 1935), mouse fleas Leptopsyllia segnis or rat lice Polyplax spinulosa (Mouffok et al., 2011;Schriefer et al., 1994). The main reservoirs are rats (Rattus rattus, $R$. norvegicus,), but various rodents and other wild and domestic animals, such as house mice, cats, opossums (Didelphis virginiana) and skunks have also been seen to act occasionally as hosts.

The third oldest known representative or rickettsiae is Rickettsia rickettsii ( $R$. rickettsii), discovered in 1904 (Wilson and Chowning, 1904) and the agent of Rocky Mountain spotted fever. The main role of ticks and tick bites as a mode of transmission was described and a first isolate obtained in 1910 (Ricketts and Wilder, 1910). The list of tick borne transmitted rickettsiae to the present day has grown enormously. Reservoirs of ricketttsiae are numerous mammals, dogs, rabbits, birds, etc. Inspection and discovery of the quantity of new, emerging, candidate rickettsiae has increased significantly. This has led to the creation of ever more modern investigative procedures and moved rickettsiology to being an elite science. An overwhelmingly large amount of scientific books and articles, describing the essence of the life and behaviour of these particular organisms have been written. There are currently 174 results accessible under the password "rickettsiae review" in PubMed.

\section{Taxonomy}

Taxonomic classification within the order Rickettsiales was originally based on relatively few phenotypic criteria (Raoult et al., 1997a). Recent decades have brought extensive reorganization with the development of molecular tools. The family Bartonellaceae (Birtles et al., 1995) and Coxiella burnetii, the agent of Q fever (Weisburg et al., 1989) and Rickettsiella grylli (Roux et al., 1997a) were removed from the order Rickettsiales, which nowadays includes three families, the Anaplasmataceae, to which belong Anaplasma, Ehrlichia, Neorickettsia, Wolbachia genera, Rickettsiaceae with Rickettsia and Orientia genera, and the Holosporaceae, which are mostly protest symbionts (Fig. 1). The bacteria from the first two families cause diseases of varying severity and are transmitted usually by arthropod vectors.

Based on the system of classification of rickettsiae, they are closely related phylogenetically and have a high degree of 16S rDNA nucleotide sequence similarity (Roux and Raoult, 1995). Recently, an international committee of expert rickettsiologists proposed guidelines to classify rickettsial isolates at various taxonomic levels and to clarify the nomenclature within the genus Rickettsia (Raoult et al., 2005). The guidelines recommended the use of multiple approaches including phenotypic, genotypic and phylogenic criteria. Five rickettsial genes have been proposed to define the genus, the group and the species: $16 \mathrm{~S}$ rRNA (rrs), gltA, ompA, ompB and sca4 (gene D) (Fournier et al., 2003). Bacteria from Rickettsia genus are divided into spotted fever groups (SFG) with causative microorganisms which are mainly spread by ticks, currently including 26 validated species; typhus group (TG) with two members, transmitted by lice and/or fleas, namely $R$. prowazekii and R. typhi; and R. bellii and R. canadensis, the latter two groups lie outside the spotted fever and typhus groups (Merhej and Raoult, 2011b).

In addition, official criteria based on epidemiological, clinical, serotypical and genotypical differences that were found after multi-spacer typing have been proposed for the creation of subspecies within $R$. conorii and $R$. sibirica complex (Zhu et al., 2005; Fournier et al., 2006a).

\section{Epidemiology}

Rickettsiae are emerging pathogens causing serious diseases in humans. The representatives of TG rickettsiae have always been linked to disastrous conditions, e.g. war, poverty, famine, catastrophe, etc. Economic decline in the standard of living and poor fundamental health choices favour their extension. $R$. prowazekii has been estimated to be responsible for several millions of deaths during and after World War I, acting in a devastating epidemic wave in the years 1917-1925 in Europe (Patterson, 1993). Epidemic 


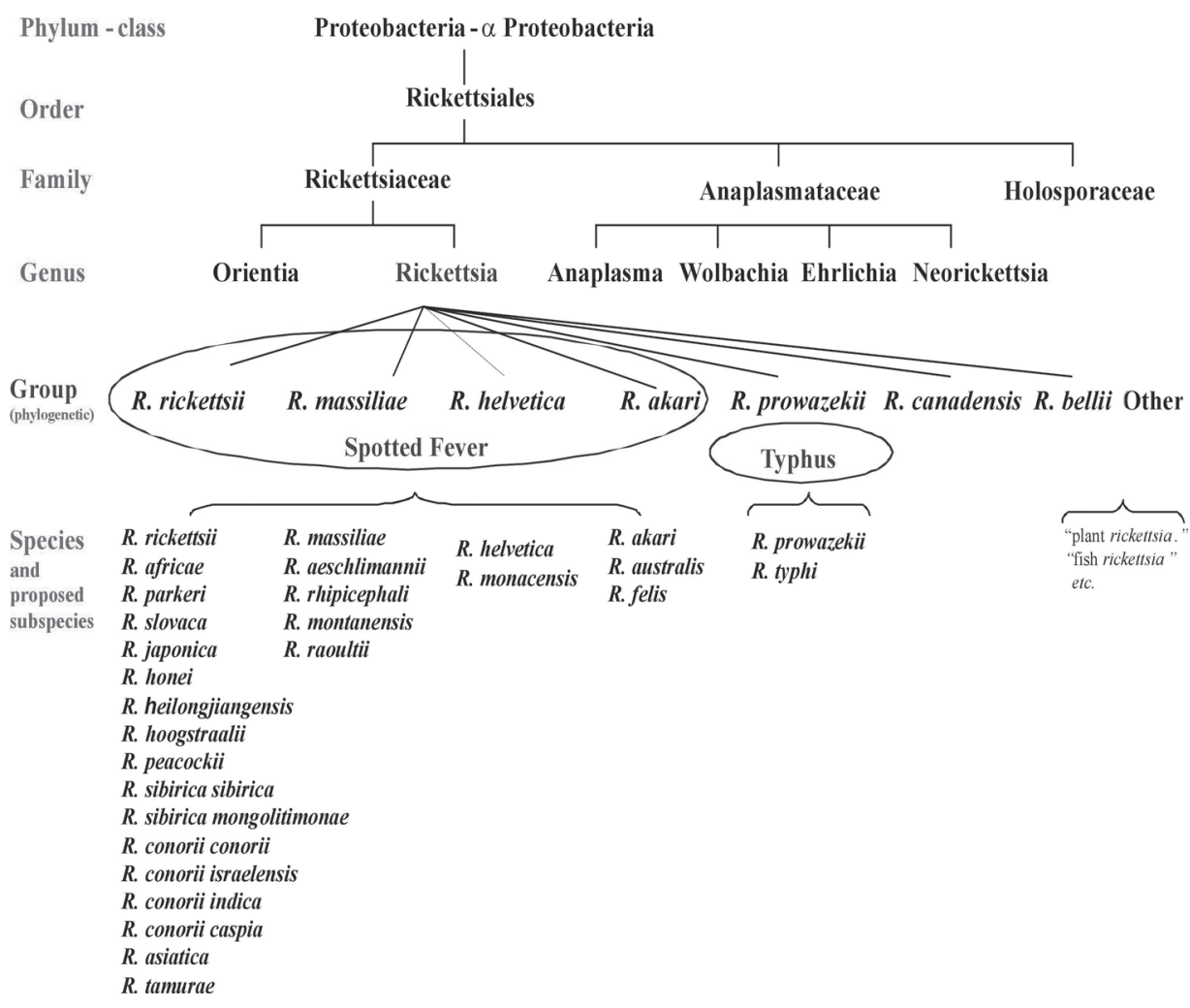

Fig. 1

Taxonomy of rickettsiae

typhus affected Napoleon's soldiers during the French retreat from Russia (Raoult et al., 2006). Again, World War II saw this problem present itself again with epidemic typhus in northern Africa, southern Italy and central and Eastern Europe. Devastating outbreaks occurred in concentration camps (Weiss, 1988). At present, R. prowazekii is considered a potential albeit unlikely category B bioterrorism agent (Walker, 2009). The majority of cases are reported from places with compromised conditions of hygiene, e.g. rural highlands of Africa. The last large outbreak of epidemic typhus was reported in Burundi during the civil war in 1997 (Raoult et al., 1997, 1998a). However, central and south America are also affected (Bechah et al., 2008a).

A complication of this disease is that under stressful conditions or weakening of the immune system, infection can be reactivated in humans, years or decades after primary onset (PRICE, 1955). The disease can be reactivated causing a recrudescent infection. Affected individuals serve as a source for re-emergence of infection during times conducive for lice (Lutwick, 2001). This supplementary element of complexity in the epidemiology of $R$. prowazekii is called Brill-Zinsser disease. Several cases of such "dormitory stage" have recently been reported in Europe keeping medical staff on high alert
(Faucher et al., 2012; Stein et al., 1999; Turcinov et al., 2000; Turcinov et al., 2002).

R. typhi, the agent of murine typhus can affect homeless people in Europe or may be reported as travel associated zoonotic disease (Leshem et al., 2011). Recently, in a French retrospective study, all murine typhus cases occurred in travellers and most of them had returned from Africa and South-east Asia (Walter et al., 2012).

SFG rickettsie comprise the family of species with genetic based differences, causing diseases which usually reflect the continent from where the bacteria originated, e.g.: $R$. rickettsii causing Rocky Mountain spotted fever; $R$. conorii - Mediterranean spotted fever (MSF); R. akari - rickettsialpox; $R$. japonica - Japanese spotted fever; $R$. sibirica sibirica- North Asian tick typhus; $R$. sibirica mongolitmonaelymphangitis-associated rickettsiosis; $R$. raoultii and $R$. slovaca-SENLAT (scalp eschar and neck lymphadenopathy following tick bites) $R$. africae - African tick bite fever, $R$. australis - Queensland tick typhus and R. honei - Flinders Island spotted fever, R. marmionii - Australian spotted fever, $R$. heilongjiangensis - Far Eastern spotted fever.

In times before the application of molecular biological methods for the detection of pathogens, MSF triggered by $R$. 
conorii, and Siberian tick typhus caused by R. sibirica subsp. sibirica, were considered to be the only rickettsiosis prevalent in Europe (Blanco and Oteo, 2006). However, seven new autochthonous tick-borne rickettsial pathogens have been described in Europe over recent decades e.g. lymphangitisassociated rickettsiosis (LAR) caused by (a) R. sibirica subsp. mongolitimonae (Fournier et al., 2006b), SENLAT (scalp eschar and neck lymphadenopathy following tick bites) (Angelakis et al., 2010) [or tick - borne lymphadenopathy (TIBOLA) (Lakos, 2002, 2012) or Dermacentor spp.- borne necrosis - erythema lymphadenopathy (DEBONEL)] which is caused by (b) R. slovaca and (c) R. raoultii (Ibarra et al., 2006), Israeli spotted fever by (d) R. conorii israelensis and Astrakhan fever by (e) R. conorii subsp. caspia (Tarasevich et al., 1991), (f) R. monacensis induced disease (Simser et al., 2002), and flu like symptoms based on the ( $\mathrm{g}$ ) R. helvetica (Beati et al., 1993b). In addition, several new Candidatus rickettsia e.g. Candidatus Rickettsia barbariae (Mura et al., 2008), "Candidatus Rickettsia AvBat" (Socolovschi et al., 2012a) have been discovered. A special chapter in the epidemiological picture of population in Europe play tickborne rickettsioses naturally occurring outside Europe, e.g. African tick-bite fever (ATBF) in patients returning from Africa (Jensenius et al., 2004a;Raoult et al., 2001;Rolain et al., 2004), or Rickettsialpox, infection caused by R. akari, commonly detected in the United states which has been recently reported in Turkey (Ozturk et al., 2003), Croatia (Radulovic et al., 1996) and France.

\section{Vectors}

\subsection{Lice}

The body louse, P. humanus corporis, is a strictly haematophagous, blood-sucking ectoparasite, that lives in clothing throughout its life cycle. They need to feed five times per day with a lifespan of about 4-12 weeks, and deposit their infected faeces near the bite lesion. $R$. prowazekii can remain viable for 100 days in lice faeces (Raoult and Roux, 1999). Transovarian transmission in the louse does not occur since lice die several weeks after being infected.

Transmission of $R$. prowazekii occurs by contamination of bite sites, conjunctivae, and mucous membranes with the faeces or crushed bodies of infected lice. Infection through aerosols of faecal dust has also been reported (Andersson and Andersson, 2000; Raoult et al., 2004). An ease of transmission provides the main risk of epidemic typhus contamination for utility staff, mainly physicians. Lice also suffer from R. prowazekii infection. After feeding on the infected person, bacteria multiply in the louse gut epithelium and are released on the rupture of infected epithelial cells. Blood enters the louse body cavity as a result of loss of the epithelial lining, the louse becomes red, and infected red lice die within 1 week (Houhamdi et al., 2002).

\subsection{Flea}

The invertebrate vectors of $R$. typhi are rat or cat fleas both of which frequently dwell close to humans. Transmission to humans occurs through contaminated skin, conjunctiva, or via the respiratory route by aerosols of contaminated flea faeces (Raoult and Roux, 1997a), or through the flea bite itself. The normal transmission cycle for murine typhus is rat-flea-rat, but accidentally rat-flea-man (X. cheopis), or cat-flea-man (C. felis). These regular modes of dispersion can be replaced by the Virginia Opossum flea cycle. Successful attempts at experimental infection with $R$. typhi were performed in Slovakia (Rehacek et al., 1976b). Fleas as possible vectors of rickettsial diseases have been studied extensively (Rehacek and Tarasevich, 1988; Rehacek et al., 1975b). R. typhi is maintained transovarially in fleas where it multiplies in the epithelium of the flea midgut. Fleas are capable of multiple feeding, and thus potentially transmitting the Rickettsia to several hosts (Civen and Ngo, 2008; Mouffok et al., 2011; Traub and Wisseman, 1978).

In addition, the cat flea, Ctenocephalides felis, is currently the only known biological vector of $R$. felis, the spotted fever agent. Recently, $R$. felis have been detected in several flea species, as well as in ticks, mites, mosquitoes and booklice suggesting a variety of arthropod hosts (Parola, 2011). Studies examining the transmission of $R$. felis using colonized cat fleas have shown a decrease in vertical transmission from one generation to other and stable horizontal transmission (Hirunkanokpun et al., 2011). R. felis transmission has been suggested to be similar to the R. typhi mechanism of transmission (Raoult et al., 1998b; Reif and Macaluso, 2009).

\subsection{Ticks}

Ecological characteristics of the tick vectors of rickettsiae influence the epidemiology and clinical aspects of tick-borne diseases (Parola and Raoult, 2001). In nature, vertebrate hosts infections may result in a rickettsemia that allows uninfected ticks to become infected and for the natural cycle to be perpetuated (Burgdorfer et al., 1966). Ticks may acquire rickettsiae through transovarial passage, via transfer of bacteria from adult female ticks to the subsequent generation of ticks via the eggs. A transstadial passage, transfer of bacteria to another stage, is a necessary component for the vectorial competence of the ticks (Parola et al., 2001). Sexual transmission of $R$. rickettsii from infected males to uninfected females cannot significantly propagate the infection in tick lineages (Schriefer. and Azad, 1994). Co-feeding transmis- 


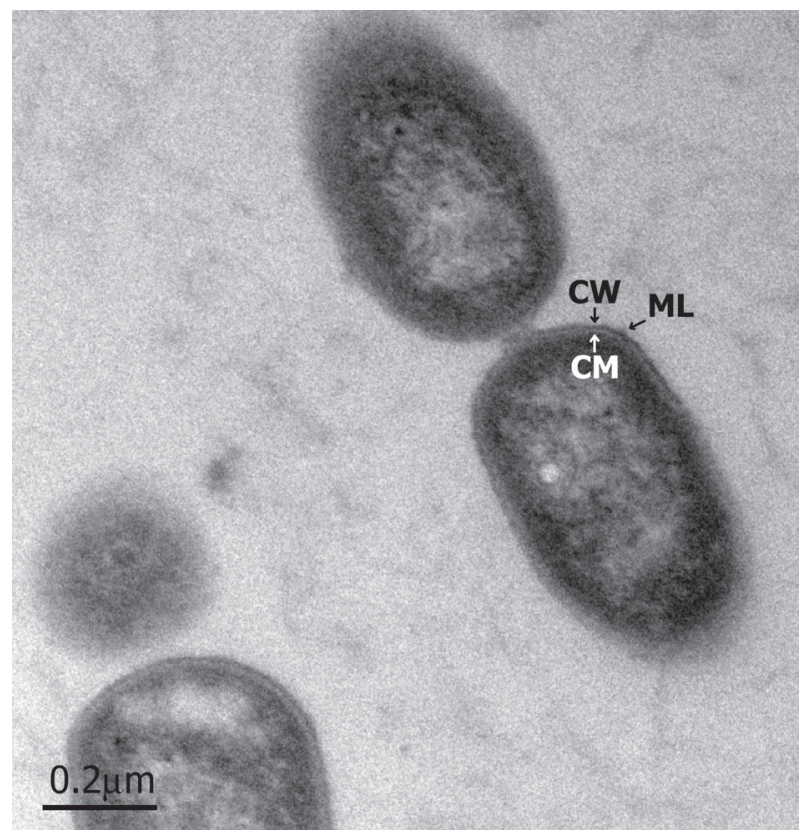

Fig. 2

Electron micrograph of binary division of rickettsiae

R. slovaca: $\mathrm{ML}=$ microcapsular layer, $\mathrm{CW}=$ cell wall, $\mathrm{CM}=$ cytoplasmic membrane.

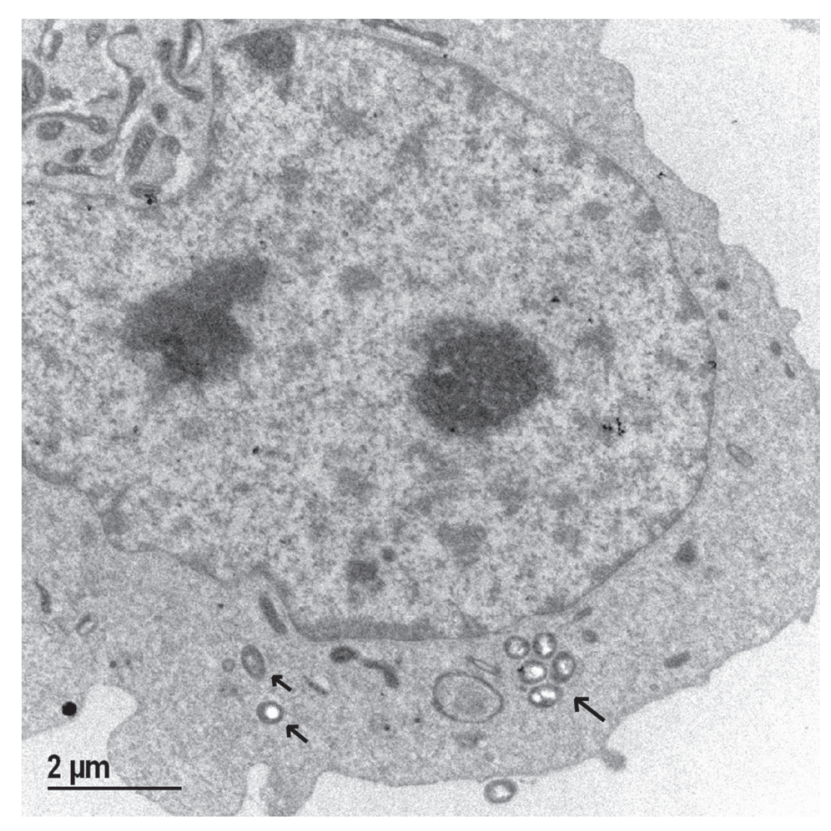

Fig. 3

Ultrathin section of L929 cells infected with $R$. slovaca Arrows are pointing to free bacteria in cytoplasm.

sion between different generations of ticks may obviate or lessen the requirement for transovarial maintenance of R. conorii (Philip, 1959).

\subsection{Other arthropod vectors}

Few other arthropods are known as vectors of rickettsial agents. A hematophagous mesostigmatid mite Liponyssoides sanguineus, the house mouse mite, is the vector of rickettsialpox, R. akari agent. The transovarial and transstadial transmission of $R$. akari occurs in this L. sanguineus mite and suggests the potential role of reservoir in the wild besides various commensal and wild rodent species (Kiselev and Volchanetskaya, 1995). The prostigmatid trombiculid mites (chiggers) are the vector for the agent of scrub typhus, Orientia tsutsugamushi, a rickettsiosis of Eurasia and northern Australia.

Recently, R. felis was detected in Anopheles gambiae mosquito molecular form $S$, which represents the major African malaria vector, collected from Côte d'Ivoire and in Aedes albopictus mosquito collected from Gabon (Socolovschi et al., 2012b,c). Mosquitoes of the family Culicidae are blood-sucking arthropods with a global distribution which are the main vector for infectious diseases. Mosquitoes are a potential vector of $R$. felis but more study is needed to confirm this hypothesis.

\section{Morphology}

Rickettsiae are usually coccobacillary in shape with dimensions ranging to about $0.7-1.0 \mu \mathrm{m}$ in length, $0.3-0.5$ $\mu \mathrm{m}$ in width. They are strict intracellular parasites, requiring host cells; even though attempts to propagate rickettsiae in axenic medium are taking place (personal communication). TG rickettsiae can be observed in the cytoplasm, SFG rickettsiae may be observed both in the nuclei and the cytoplasm of host cells (Boldis et al., 2009; Silverman, 1991). Capsular material surrounding the cell wall can be seen in electron micrographs of fresh preparations as well as intracytoplasmic invaginations of the plasma membrane (mesosomes) and ribosomes. The bacterial surface exhibits a trilaminar construction composed of an inner (cytoplasmic membrane), outer leaflet (Tamura et al., 1995), and microcapsular layer on the outside of the cell wall (Figs. 2, 3).

The bacterial wall is chemically similar to that of gramnegative bacteria as it contains diaminopimelic acid and lacks teichoic acid (Silverman and Wisseman, Jr., 1978; Silverman et al., 1978a,b). The presence of a lipopolysaccharide (LPS) layer, typical of gram negative bacteria (Wisseman, Jr., 1968) indicates high endotoxic potency of rickettsiae (Zahringer, 1994). The structural properties of LPS from R. typhi and $R$. prowazekii have revealed a chemical similarity to that of Proteus vulgaris OX19 (Amano et al., 1998). Lipid A of $R$. typhi resemble classic hexaacyl lipids A forms known by enterobacteria (Fodorova et al., 2011).

Confocal, scanning electron, and transmission electron microscopy has revealed induced polymerization of host cell 
actin (Van Kirk et al., 2000). So called actin-based motility (ABM) employed by SFG rickettsiae, promotes intracellular and cell-to-cell spread (Heinzen, 2003).

\section{Isolation}

Rickettsiae can be grown in vitro in tissue cell cultures (Vero, L929, HEL, XTC-2, or MRC5 cells), using the centrifugation shellvial technique (Vestris et al., 2003), or maintained in living host cells (animal mouse models or embryonated eggs). Isolation attempts must only be carried out in biosafety level 3 laboratories. They can be performed in various modes. A minimum of $5 \mathrm{ml}$ of blood collected prior to antimicrobial therapy, routinely by using buffy coat preparations of heparinized or EDTA-anticoagulated whole blood (decanted plasma, collected on heparin or citrate anticoagulant) can be applied. Skin biopsy specimens (inoculation eschar being the best to use) are an excellent source of rickettsiae, and of course vectors, arthropods (crushed ticks are mostly used). Culturing may be time consuming as new isolates need time to adapt to laboratory growth conditions, and a certain percentage of samples may be contaminated by other pathogens. Only one third of isolation attempts are successful. Although they possess a membrane resembling a gram-negative bacterium, they are usually not stained with Gram techniques, but frequently with
Gimenez staining method (Gimenez, 1964). Light microscopy has shown that the maximum accumulation of SFG rickettsiae is between days 5-7 and cell death was apparent $7-10$ days post infection. Later stages of infection were characterized by necrotic effect of the infected cultures.

In common with many other intracellular pathogens, rickettsiae utilize a "zipper" mechanism to mediate their cellular internalization (Ham et al., 2011). Rickettsiae exploit the cytoskeleton to enter and spread within the host cell. Although these bacteria are able to make all metabolites necessary for growth, they have an ATP transport system that allows them to use host ATP. Thus, they are energy parasites as long as ATP is available from the host (Winkler and Daugherty, 1984). They divide by binary fission and metabolize host-derived glutamate via aerobic respiration and the citric acid cycle (Coolbaugh et al., 1976; Rees, Jr. and Weiss, 1968). Differences in cytopathic effects are known, however parameters of mechanisms of oxide injury are not completely elicited (Eremeeva et al., 2001).

\section{Genetic coding for intracellular activities}

The rickettsiae have guanine plus cytosine $(\mathrm{G}+\mathrm{C})$ content of $29 \%$ to $32.6 \%$, and a genomic size varying between $1.1 \mathrm{Mb}$ and $1.59 \mathrm{Mb}$ (Rickettsia endosymbiont of I. scapularis was

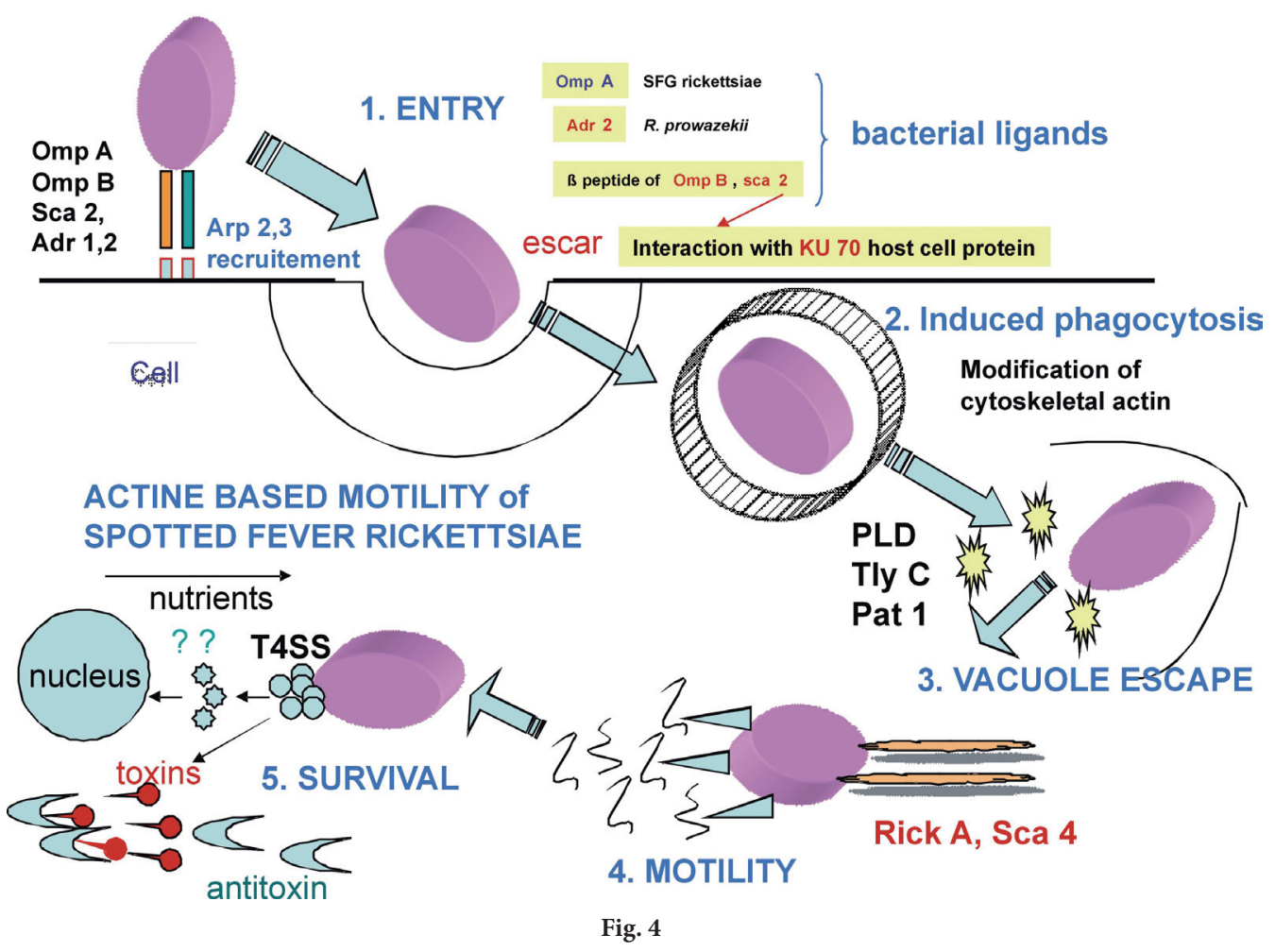

Intracellular behavior of rickettsiae 
described to be 2.1). Knowledge of genomes has provided new insight into the functions that are required by rickettsiae for their survival in the animal host (Palmer, 2002) (Fig. 4). It has been considered that gene loss can be a critical feature of the evolution of intracellular pathogenic bacteria (Andersson and Andersson, 1999; Andersson and Kurland, 1998; Blanc et al., 2007; Darby et al., 2007). All rickettsiae share two outer membrane proteins (OmpB and Sca4) and LPS biosynthesis machinery. The genome of $R$. typhi contains four potentially membranolytic genes (tly $A, t l y C$, pld $A$, and pat-1) and five autotransporter genes, sca1, sca2, sca3, ompA, and $o m p B$. Each of these genes plays a crucial role in life of rickettsiae within cells.

Genetic alterations, e.g. the disruption of rickettsial outer membrane proteins ( $r O m p A$ and $r O m p B)$, coding for so called "attachment to cells proteins" were shown to play vital roles in adhesion and invasion of rickettsiae into mammalian cells, providing an essential condition for further spread of infection (Chan et al., 2009; Li and Walker, 1998). The cell surface antigen sca4 of Rickettsia co-localizes with vinculin in cells at sites of focal adhesions in sca4-transfected cells. Sca4 binds to and activates vinculin through two vinculin binding sites that are conserved across all Rickettsia (Park et al., 2011). Traversal of host cell membrane is probably enabled by tlyA gene coding for Hemolysin A (Walker and $\mathrm{Yu}, 2005)$. Sca2 gene has been associated with adherence (Cardwell and Martinez, 2009) and actin-based motility (Kleba et al., 2010). Disruption of this gene led to no fever status after the $R$. rickettsii infection.

Following binding of rickettsiae to host cells and associated cytoskeletal rearrangements, the bacterium is engulfed by a cellular vacuole. Rickettsiae can penetrate nonphagocytic cells by induced phagocytosis (Teysseire et al., 1995). Once phagocytised, Rickettsia spp. tends to rapidly escape the vacuole entering the cytoplasm of the host cell (Teysseire et al., 1995). It is likely that this rapid escape is instrumental to the survival of these microbes, prior to the fusion of lysosomes. Phagosomal membrane escape is due to thyC and pld genes with membranolytic activity, coding for Hemolysin C and Phospholipase D (Olano, 2005; Renesto et al., 2003; Walker et al., 2001), respectively.

Once within the cytoplasm, SFG rickettsiae demonstrate actin-based motility (ABM), probably facilitating their spread. RickA is essential for interaction with the multisubunits of the eukaryotic Arp 2/3 complex, among other genes, regulating the actin cytoskeleton responsible for ABM (Balraj et al., 2008). Members of TG: R. prowazakii, R. typhi, and $R$. peacockii of the SFG do not possess functional rickA protein (Teysseire et al., 1995). Hence, motility may take part in, but cannot explain per se the differences in pathogenicity. It has been shown, that the disruption and gene loss defective process can contribute to the avirulence of ricketsiae (Ellison et al., 2008). On the other hand, a massive comparative genomic analysis of gene loss in intracellular bacteria, underlined the hypothesis that such a state enables a pathogen to enhance virulence (Darby et al., 2007; Merhej et al., 2009). Comparison of $R$. africae and $R$. rickettsii has pointed to regulatory genes as essential factors in the development of pathogenicity (Fournier et al., 2009).

The first genome of a tick-transmitted rickettsia ( $R$. conorii strain Seven) was fully sequenced in 2001 (Ogata et al., 2001). At present a complete genome sequence of 24 validated species is known, and several other rickettsial genomic projects are running. Genomes portray the key features of rickettsial intracellular survival (Walker et al., 2005). Comparative genomics enables unveiling of functions of their construction units, and opens up a new, genomic era (Table 1).

\section{Detection}

Guidelines for the diagnosis of tick-borne bacterial diseases in Europe were proposed by Brouqui et al. (2004). Clinical symptoms and epidemiological history together with laboratory confirmation should all be taken into consideration in order to make the correct diagnosis. The complement fixation test of the past times serology was replaced by a test of first choice microimmunofluorescence (Kelly et al., 1992b), followed by the latex agglutination, indirect hemagglutination, immunoperoxidase assay, and enzyme-linked immunosorbent assay (Kovacova and Kazar, 2000; Kovacova et al., 2006). Five ml of blood should be collected early in the course of the disease, followed by a second sample taken 2 weeks later. If possible, a third sample should be collected 4-6 weeks later. Sera can be preserved at $-20^{\circ} \mathrm{C}$ or lower for several months without degradation of the antibodies. A harvest of a few drops of blood onto blotting paper screened for positive reaction was proposed as an alternative method (Fenollar and Raoult, 1999). MIF is widely accepted as the reference method (La Scola and Raoult, 1997). IgG titres of 64 or more and/or IgM titres of 32 or more are considered to be indicative of infection by other Rickettsia species in other rickettsioses. IgM and IgG antibodies are detectable separately in acute and convalescent sera. IgG titres of 128 or above and/or IgM titres of 64 or above are considered to be indicative of infection by $R$. conorii conorii in suspected cases of MSF. Both IgM and IgG antibodies are usually detectable between 7 and 15 days after the onset of the disease. However, response to R. africae is delayed, a seroconversion in patients was detected 28 and 25 days after the onset of symptoms (Fournier et al., 2002).

The interpretation of serological data can be confounded by the cross-reactivity that occurs between SFG rickettsiae and/or other bacteria (Parola et al., 2005; Raoult and Dasch, 1995). Therefore, western blotting was suggested as a method of choice which will detect false positive results. Neverthe- 
Table 1. Rickettsia organisms' genome overview, genomic projects annotation report

\begin{tabular}{|c|c|c|c|c|c|c|}
\hline No. & Organism & Strain, subspecies name & Causative agent & Size & NCBI link & Related publication \\
\hline \multirow[t]{2}{*}{1.} & \multirow[t]{2}{*}{ Rickettsia prowazekii } & Madrid E & \multirow[t]{2}{*}{ Epidemic typhus } & \multirow[t]{2}{*}{1,11} & AJ235269 & \multirow[t]{2}{*}{$\begin{array}{l}\text { Bechah et al. (2010); Andersson et al. } \\
\text { (1998) }\end{array}$} \\
\hline & & $\begin{array}{l}\text { BuV67-CWPP } \\
\text { Chernikova } \\
\text { Dachau } \\
\text { RpGvF24 } \\
\text { Rp22 } \\
\text { GvV257 } \\
\text { Katsinjan } \\
\end{array}$ & & & $\begin{array}{l}\text { CP003393 } \\
\text { CP003391 } \\
\text { CP003394 } \\
\text { CP003396 } \\
\text { CP001584 } \\
\text { CP003395 } \\
\text { CP003392 } \\
\end{array}$ & \\
\hline 2. & R. typhi & $\begin{array}{l}\text { Wilmington } \\
\text { B9991CWPP } \\
\text { TH1527 } \\
\end{array}$ & Murine typhus & 1,11 & $\begin{array}{l}\text { AE017197 } \\
\text { CP003398 } \\
\text { CP003397 } \\
\end{array}$ & McLeod et al. (2004) \\
\hline 3. & R. rickettsii & $\begin{array}{l}\text { Iowa ASM1744v1 } \\
\text { Hlp\#2 } \\
\text { Arizona } \\
\text { Brazil } \\
\text { Colombia } \\
\text { Hauke } \\
\text { Hino } \\
\text { ShelaSmith }\end{array}$ & $\begin{array}{l}\text { Rocky mountain } \\
\text { spotted fever }\end{array}$ & 1,27 & $\begin{array}{l}\text { CP000766 } \\
\text { CP003311 } \\
\text { CP003307 } \\
\text { CP003305 } \\
\text { CP003306 } \\
\text { CP003318 } \\
\text { CP003309 } \\
\text { CP000848 } \\
\end{array}$ & Ellison et al. (2008b) \\
\hline 4. & R. conorii complex & $\begin{array}{l}\text { conorii } \\
\text { Malish } 7 \\
\text { caspia } \\
\text { A-167 } \\
\text { indica ITTR } \\
\text { israelensis } \\
\text { ISTT CDC1 } \\
\end{array}$ & $\begin{array}{l}\text { Indian tick typhus } \\
\text { Israeli spotted } \\
\text { fever }\end{array}$ & $\begin{array}{l}1,27 \\
1,26\end{array}$ & $\begin{array}{l}\text { AE006914 } \\
\text { AJUR00000000 } \\
\text { AJHC00000000 } \\
\text { AJVP00000000 }\end{array}$ & $\begin{array}{l}\text { Sentausa et al. }(2012 \mathrm{~b}, \mathrm{c}, \mathrm{d}) \text {; Ogata et al. } \\
(2000,2001 \mathrm{~b})\end{array}$ \\
\hline 5. & R. sibirica complex & $\begin{array}{l}\text { sibirica } \\
246 \\
\text { sibirica BJ-90 } \\
\text { mongolitimonae HA-91 }\end{array}$ & $\begin{array}{l}\text { Siberian tick } \\
\text { typhus } \\
\text { Lymphangitis- } \\
\text { associated rick- } \\
\text { ettsiosis }\end{array}$ & 1,25 & $\begin{array}{l}\text { AABW00000000 } \\
\text { AHIZ00000000 } \\
\text { AHZB00000000 }\end{array}$ & $\begin{array}{l}\text { Sentausa et al. (2012a,e); Malek et al. } \\
(2004)\end{array}$ \\
\hline 6. & R. slovaca & $\begin{array}{l}\text { 13-B } \\
\text { D-CWPP }\end{array}$ & SENLAT & 1,28 & $\begin{array}{l}\text { CP002428 } \\
\text { CP003375 }\end{array}$ & Fournier et al. (2012) \\
\hline 7. & R. massiliae & $\begin{array}{l}\text { MTU5 } \\
\text { AZT80 }\end{array}$ & Spotted Fever & $\begin{array}{l}1,38 \\
1,28 \\
\end{array}$ & CP00683 & Blanc et al. (2007a) \\
\hline 8. & R. africae & ESF-5 & $\begin{array}{l}\text { African tick bite } \\
\text { fever }\end{array}$ & 1,29 & СР00612 & Fournier et al. (2009b) \\
\hline 9. & R. helvetica & C9P9 & Spotted fever & 1,42 & AICO00000000 & Dong et al. (2012a) \\
\hline 10. & R. montanensis & OSU $85-930$ & & 1,28 & CP003340 & - \\
\hline 11. & R. rhipicephali & 3-7-female6-CWPP & & 1,31 & CP00342 & - \\
\hline 12. & R. parkeri & Portsmouth & Spotted fever & 1,30 & CP003341 & - \\
\hline 13. & "R. philipii" & $364 \mathrm{D}$ & Spotted fever & 1,29 & Cp003308 & - \\
\hline 14. & R. japonica & $\begin{array}{l}\mathrm{YH} \\
\mathrm{YH}^{*}\end{array}$ & $\begin{array}{l}\text { Japanese or } \\
\text { oriental spotted } \\
\text { fever }\end{array}$ & 1,28 & $\begin{array}{l}\text { Ap011533 } \\
\text { AMRT00000000 }\end{array}$ & - \\
\hline 15. & R. heilongjiangensis & & $\begin{array}{l}\text { Far Eastern tick- } \\
\text { borne rickettsiosis }\end{array}$ & 1,28 & CP002912 & Duan et al. (2011) \\
\hline 16. & R. peacockii & Rustic & - & 1,31 & $\mathrm{CO} 001227$ & Felsheim et al. (2009) \\
\hline 17. & R. honei & $\mathrm{RB}$ & $\begin{array}{l}\text { Flinders Island } \\
\text { spotted fever }\end{array}$ & 1,27 & AJTT00000000 & Xin et al. (2012) \\
\hline 18. & R.felis & URRWXCal2 & Spotted Fever & 1,59 & $\mathrm{CP} 000053$ & Ogata et al. (2005) \\
\hline 19. & R. akari & Hartford & Rickettsialpox & 1,23 & CP000847 & - \\
\hline 20. & R. australis & $\begin{array}{l}\text { Cutlack } \\
\text { Phillips }\end{array}$ & $\begin{array}{l}\text { Queensland Tick } \\
\text { Typhus }\end{array}$ & $\begin{array}{l}1,32 \\
1,32 \\
\end{array}$ & $\begin{array}{l}\text { CP003338 } \\
\text { AKVZ00000000 }\end{array}$ & Dong et al. (2012b) \\
\hline 21. & R. bellii & $\begin{array}{l}\text { RML369-C10.2 } \\
\text { OSU 85-389 } \\
\end{array}$ & - & $\begin{array}{l}1,52 \\
1,53 \\
\end{array}$ & $\begin{array}{l}\text { CP000087 } \\
\text { CP000849 } \\
\end{array}$ & Ogata et al.(2006) \\
\hline 22. & R. canadensis & $\begin{array}{l}\text { McKiel } \\
\text { CA410 } \\
\end{array}$ & $\begin{array}{ll}- \\
-\end{array}$ & $\begin{array}{l}1,16 \\
1,15 \\
\end{array}$ & $\begin{array}{l}\text { CP000409 } \\
\text { CP003304 } \\
\end{array}$ & \\
\hline 23. & $\begin{array}{l}\text { Candidatus "R. } \\
\text { amblyommii" }\end{array}$ & GAT-30V & - & 1,48 & NC017028 & $\begin{array}{l}\text { Burkhardt et al. (2011); Baldridge et } \\
\text { al. (2010) }\end{array}$ \\
\hline 24. & $\begin{array}{l}\text { Rickettsia endosymbi- } \\
\text { ont of Ixodes scapularis }\end{array}$ & & - & 2,1 & CM000770 & - \\
\hline
\end{tabular}

SENLAT: scalp eschar and neck lymphadenopathy after tick-bite. 
less this technique is suited to reference laboratories only (Jensenius et al., 2004b).

Distinct differences in DNA based composition between the typhus and SFG of rickettsiae were established long time ago (Tyeryar, Jr. et al., 1973). Application of molecular biology techniques, a sensitive specific and rapid tool to detect and identify rickettsiae, caused the emergence of several new species. This technique can be used to find the agent in vectors (ticks), in EDTA-anticoagulated blood, in eschar/ crust swab or skin biopsies. Samples can be taken directly from eschar ("tâche noire") being the most useful specimen. The usefulness of noninvasive cutaneous swab specimens for detecting rickettsiae was recently analyzed in animal model (guinea pigs) and in several humans (Bechah et al., 2011). Specimens from eschars were positive for rickettsiae as long as lesions were present. Optimal storage temperature for specimens was $4^{\circ} \mathrm{C}$ for 3 days. In a prospective study in Algeria on autochthonous rickettsioses and in a retrospective study on travellers from South Africa (Mouffok et al., 2011; Socolovschi et al., 2012d), eschar/crust swab from inoculation eschar showed the same sensibility and specificity as skin biopsy sample. In addition, this test can be used at bedsides or in outpatient clinics and could be useful for epidemiologic, clinical studies and is also preferred by patients.

A current trend applied in most screening laboratories is on PCR, amplifying sequences of species specific genes. OmpA (Fournier et al., 1998), ompB (Roux and Raoult, 2000), gltA (Roux et al., 1997b), and gene D (sca4) (Sekeyova et al., 2001) are reliable determinations of rickettsiae on the species level. Primer sets targeting rickettsial genes can be used in any laboratory with suitable facilities (Fig. 5). Technical progress determined the next steps of rickettsial detection. The multi-locus sequence typing (MLST) scheme was proposed as an alternative proportional system successfully used to detect variability among the Rickettsiae (Vitorino et al., 2007a). Multi-spacer typing based on three intergenic spacers achieved identification of rickettsiae at species level also (Fournier and Raoult, 2007).

A real-time quantitative PCR has increased sensitivity of detection. A positive correlation between the bacteria copies and culture, the isolation success in skin biopsies and ticks, has recently been described (Angelakis et al., 2012). Culture remains critical for strain analysis.

Genomic era, a comparison of whole genomes is more likely to become a comparative method in the future but for now can only be performed in specialized laboratories.

\section{Pathology}

The clinical presentation of rickettsial diseases can vary from mild to very severe. The case-fatality rate for highly virulent rickettsiae ranges from $2 \%$ to more than $30 \%$
(Azad, 2007; Raoult and Maurin, 2002; Raoult and Roux, 1997a). Epidemic typhus $R$. prowazekii usually manifests after an incubation period of 10-14 days. Typhus group rickettsiae can cause severe pathological changes in an organism leading to ruthless disorders and if untreated, inevitably resulting in a fatal outcome (Bechah et al., 2008 b). Rash can be apparent only in half of the patients suffering from the murine typhus disease in contrast with epidemic typhus when patients suffer from purpuric rash over the course of the illness. An extensive multi system disease can develop; fever, cough, headache, diarrhoea, muscle pain, rash, local lymphadenopathy (in some cases) splenomegaly, conjunctivitis and myalgia (disseminated in later stages), affecting the disorders of brain functionality, lymphohistocytic vasculitis of the central nervous system, lung, liver, kidney, heart (endothelia), leading to diffuse alveolar damage and haemorrhage, interstitial pneumonia, pulmonary oedema, interstitial myocarditis and nephritis, portal triaditis, and cutaneous, mucosal, and serosal haemorrhages (Raoult et al., 1986, 1997a, 1998b;Walker, 2007; Walker and Ismail, 2008). Nonspecific haematological and biochemical findings include thrombocytopenia, leucocyte count abnormalities and elevated hepatic enzyme levels (Brouqui et al., 2004).

However, clinical signs vary depending on the rickettsial species involved. As for SFG rickettsiae, incubation time of 6-14 days after the bite of infected vector necessitates development of the disease. Typically, the clinical symptoms of SFG rickettsiae include a characteristic inoculation eschar ("tâche noire") at the site of the bite. The systemic infection leads to vasodilatation, which can be present in $60-80 \%$ of patients only. The rash can be (a) macular (in case of evolution of the disease into perivascular oedema), maculo-papular (in MSF). (b) Vesicular form can be seen in rickettsialpox or African tick-bite fever. (c) Profuse or composed of a few cutaneous elements as has been reported in a lymphangitis-associated type of rickettsiosis. Disruption of vascular integrity leads to (d) petechial rash for $R$. rickettsii infection. The rash can also be (e) nonspecific. New clinical signs and features have recently been described in rickettsioses such as: lymphangitis in $R$. sibirica mongolitimonae infection (LAR), cervical lymphadenopathy for $R$. raoultii and $R$. slovaca infection (SENLAT), and multiple eschars in MSF.

\section{Treatment}

The differences on the species level are not the only explanation for the disease outcome. Host associated factors, e.g. age, occupational bias, reduced access to health care facilities or antibiotic treatment are part of the building blocks determining the course of the illness. In vitro studies 


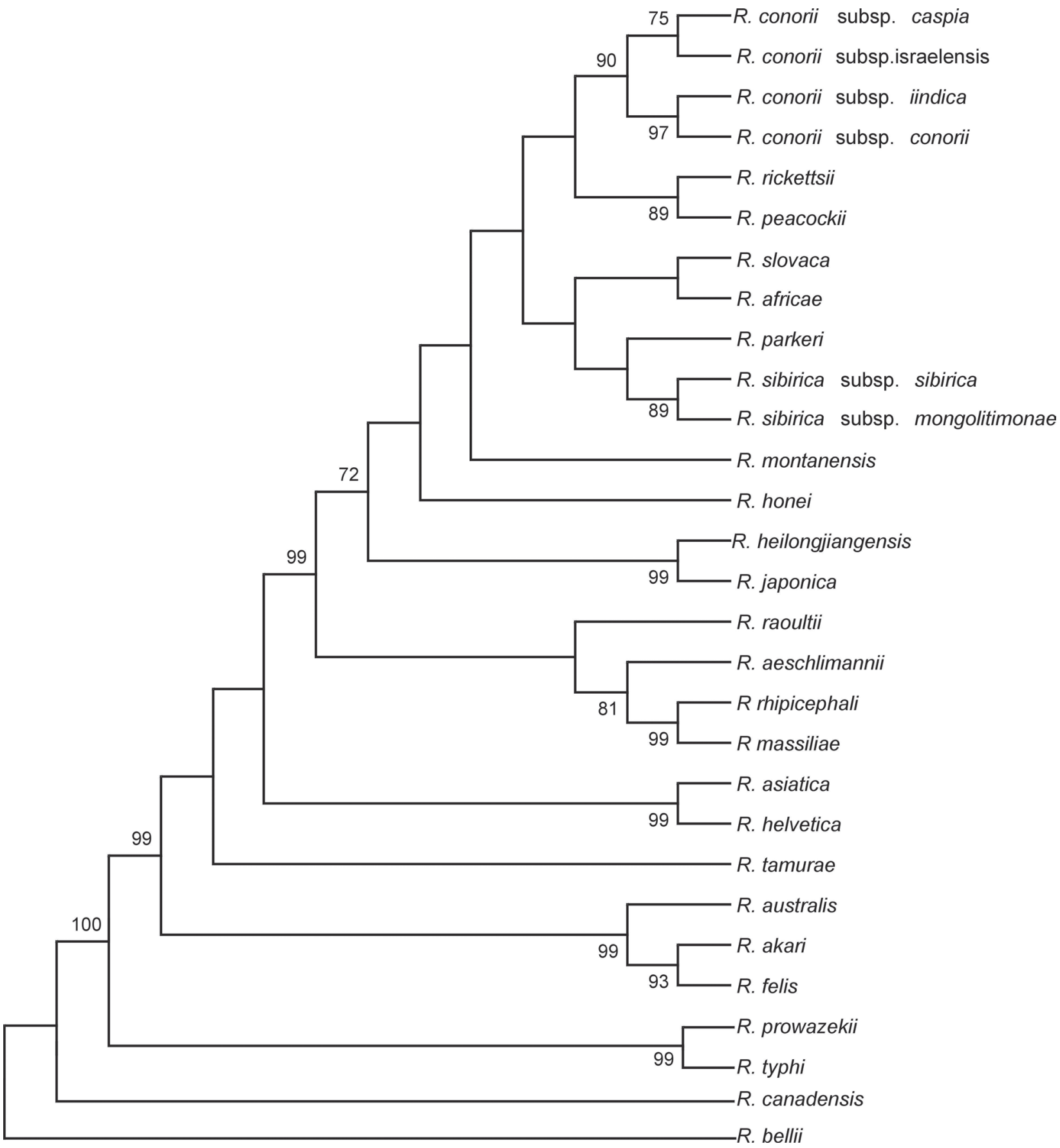

Fig. 5

Phylogenetic organization of rickettsia species and subspecies inferred from the comparison of sequences from the scal gene using the maximum likelihood method Numbers at the nodes are boostrap values exceeding $70 \%$

of antibiotic susceptibilities have been done in order to find the right treatment (Rolain et al., 1998).

Doxycycline remains the first-line antibiotic therapy for patients with rickettsial diseases. The conventional antibiotic regimen for SFG rickettsioses is a 7-14-day oral course of doxycycline, $200 \mathrm{mg}$ daily (Raoult et al., 2002). In severely diseased patients, the intravenous route should be used first to administer doxycycline at $200 \mathrm{mg}$ daily, and prolonged 
duration, up to 3 days following apyrexia, should be considered (Brouqui et al., 2007).

Doxycycline and azithromycin are safe and effective for the treatment of SENLAT. Starting early treatment is highly recommended (Ibarra et al., 2005). Tetracyclin are the most effective antibiotic against $R$. rickettsii and $R$. conorii. However, they are contraindicated during pregnancy (Raoult. et al., 2002). Short-course therapy with doxycycline (one dose of $200 \mathrm{mg}$ ) has been reported to be as effective for MSF as a 10-day course and is well tolerated, even in children (Bella-Cueto et al., 1987; Lochary et al., 1998). Indeed, only the long-term or repeated use of doxycycline remains contraindicated in children younger than 8 years of age because of tooth coloration; short course of treatment can therefore be used safely. Interestingly, Cascio et al., reported no more dental defects in children $<8$ years treated 3 weeks with minocycline compared to controls (Cascio et al., 2004).
Josamycin may represent an alternative to tetracyclines in pregnant women, but clinical data is lacking. Fluoroquinolones, including pefloxacin, ofloxacin and ciprofloxacin, have been shown to be effective for the treatment of MSF (Raoult and Maurin, 1998) and a safe alternative to tetracycline. However, it was demonstrated in vitro that ciprofloxacin, although effective, induced a deleterious effect in cells infected with $R$. conorii due to the up-regulation of the toxin-antitoxin module vapC-vapB (Botelho-Nevers et al., 2012). Recently, in a retrospective study, fluoroquinolone treatment increased significantly and independently MSF severity and was associated with a significantly longer hospital stay (Botelho-Nevers et al., 2011). Chloramphenicol (administered for at least 1 week) has long been considered the main alternative for rickettsial infections, however, the potential risk of aplastic anaemia and acute haemolytic anaemia in patients with the Mediterranean form of G6PD deficiency, and its contrain-

\begin{tabular}{|c|c|c|}
\hline Rickettsia name & Erythromycin & Rifampin \\
\hline R. sibirica & $\mathrm{R}$ & $S$ \\
\hline R. mongolotimonae & $\mathrm{R}$ & $\mathrm{S}$ \\
\hline R. parkeri & $\mathrm{R}$ & $S$ \\
\hline$R$. africae & $\mathrm{R}$ & $S$ \\
\hline R. Conorii complex & $\mathrm{R}$ & $\mathrm{S}$ \\
\hline R. slovaca & $\mathrm{R}$ & $S$ \\
\hline R. raoultii & $\mathrm{R}$ & $\mathrm{R}$ \\
\hline Thai-tick typhus rickettsia & $\mathrm{R}$ & $S$ \\
\hline R. honei & $\mathrm{R}$ & $\mathrm{S}$ \\
\hline R. rickettsii & $\mathrm{R}$ & $S$ \\
\hline R. japonica & $\mathrm{R}$ & $\mathrm{S}$ \\
\hline Bar 29 & $\mathrm{R}$ & $\mathrm{R}$ \\
\hline R. massiliae & $\mathrm{R}$ & $\mathrm{R}$ \\
\hline R. rhipicephali & $\mathrm{R}$ & $\mathrm{R}$ \\
\hline R. aeschlimanii & $\mathrm{R}$ & $\mathrm{R}$ \\
\hline R. montana & $\mathrm{R}$ & $\mathrm{R}$ \\
\hline R. helvetica & $\mathrm{R}$ & S \\
\hline R. australis & $\mathrm{R}$ & $\mathrm{S}$ \\
\hline R. acari & $\mathrm{R}$ & S \\
\hline R. typhi & $\mathrm{S}$ & S \\
\hline R. prowazekii & $\mathrm{S}$ & S \\
\hline R. canada & $\mathrm{R}$ & $\mathrm{S}$ \\
\hline R. bellii & $\mathrm{R}$ & $S$ \\
\hline
\end{tabular}

Resistance to rifampin

has been shown to occur also in:

Mycobacterium tuberculosis,

Mycobacterium leprae,

Escherichia coli, and Neisseria meningitis

Mutations in the $r p o B$ gene encoding the beta subunit of the RNA polymerase

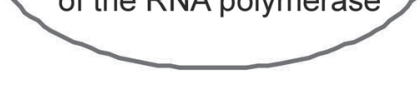

Fig. 6

High levels of susceptibility to macrolides 
dication in pregnant women, reduced the possibility of its application ((Brouqui et al., 2007)). Macrolide compounds may represent a safe alternative for children and pregnant women. However, sensitivity or resistance has to be taken into consideration with all antibiotics (Fig. 6). A genome comparison analysis of molecular mechanisms of resistance to antibiotics in the Rickettsia genus was studied (Rolain and Raoult, 2005) yet, this topic is still open. The mode of resistance is similar to other bacteria. There are certain antibiotics that are contraindicative for treatment. Co-trimoxazole is not only unhelpful for the treatment of rickettsioses, but may potentially worsen the outcome of the disease (Beltran and Herrero, 1992).

\section{Rickettsiae in Slovakia}

\subsection{Arthropod vectors in Slovakia}

Five genera (Argas, Dermacentor, Haemaphysalis, Ixodes, Hyalomma) and 21 species of soft and hard ticks have been recognized in fauna of Slovakia. I. ricinus, D. marginatus, $D$. reticulatus, $H$. concinna, $H$. punctata, and $H$. inermis are main exophillic tick species occurring in studied localities (Cerny, 1972; Rehacek et al., 1975a, 1991). I. ricinus ticks are widely distributed throughout the whole country, whereas D. reticulatus and D. marginatus ticks are limited along rivers, places of steppe, forest steppe and the karst region, respectively. D. marginatus is very common in uncultivated pastures, from where it spreads on the fallow, bushy ridges between fields and field paths (Bullova et al., 2009; Nosek, 1972). Its presence was determined along the rivers in the South-east (Latorica) as well as in the South-west (March, Danube). However at present, D. reticulatus has extended the range of its former habitats to higher altitude. It can be found at least $200 \mathrm{~km}$ further north. H. concinna occurs in the swampy woods along the river March, in the hornbeam-oak forests of the Little Carpathians and in swampy woods in the area Bratislava-Dvorniky-Štúrovo. It is especially abundant in the forests between Bratislava and Gabčíkovo and in the oak woods and Robinia pseudaccacia plantations in the neighbourhood of Jarok-near-Nitra. $H$. inermis occurs on the Kováčské Hill, and in the west of the Štiavnické Mountains, where it lives in climatically favourable localities in the river-basins of Štiavnička and Hron (in the environs of Benadik). The distribution of $H$. punctata is approximately the same as that of D. marginatus (Nosek and Grulich, 1967).

Recently, the abundance and distribution of fleas (Siphonaptera) on small mammals (rodents and insectivores) in central and eastern Slovakia have been studied (Stanko et al., 2006). Thirteen flea species were collected on 9 host species and the most abundant was Ctenophthalmus agyrtes Heller on Apodemus flavicollis Melchior. In addition, infestation as well as parasitisation of humans with flea Ctenocephalides felis, cat fleas, was recorded in the basements of flat blocks in the central area of Košice (Pet'ko, 1993).

In 45 winter nests of the common mole (Kocianova and Kozuch, 1988) from the Záhorska lowland (western Slovakia), 7 flea species with the eudominant species Ctenophthalmus assimilis were found in them and the other species were subrecedent. The acarinium of the mole winter nests was composed of 19 mite species. Predominant were euryphagous species Haemogamasus nidi, H. hirsutus, Eulaelaps stabularis, and Androlaelaps fahrenholzi (Kocianova et al., 1988).

\subsection{SFG rickettsiae detected and/or isolated in Slovakia}

The study of rickettsiae has had a long tradition. They have been in the "crosshairs" scope of the Department of Rickettsiology at the Institute of Virology in Slovakia since 1956. Occurrence of rickettsiae has been continuously monitored and the presence of six rickettsial species has been confirmed, mostly in localities of the southern part of Slovakia (Fig. 7), including five species transmitted by ticks: $R$. slovaca, $R$. raoultii, $R$. monacensis strain IRS3 and IRS4, $R$. helvetica and $R$. conorii conorii; one rickettsial species usually transmitted by ticks $R$. africae but identified in fleas in Slovakia. In addition in 1975, rickettsiae of the SFG were also found in fleas and mites by smears method of detection of rickettsia in arthropods using the immunofluorescence technique and antibody response in mice inoculated with infected arthropods which was found to be the most effective in these studies (Rehacek et al., 1975b).

\subsubsection{Rickettsia slovaca}

$R$. slovaca was the first species found to be common in Slovakia (Brezina et al., 1969). The isolate originating from D. marginatus ticks was collected in central Slovakia in 1968. It was first classified as a species closely related to $R$. sibirica (indicated as "B" or " $D$ ") but ten years later it was identified as a new species (Urvolgyi and Brezina, 1978). Several studies were provided in the next 20 years after its initial discovery (Rehacek et al., 1990). Ever since this species has been detected in many other countries, e.g. in Armenia (Rehacek et al., 1977), Ukraine (Urvolgyi et al., 1978), Yugoslavia (Manor et al., 1992), Crimea (Balayeva et al., 1993), France (Beati et al., 1993a), Switzerland (Beati et al., 1994), Portugal (Bacellar et al., 1995) etc. there appear to be no boundaries to stop this agent (Tian et al., 2012). In 1998, on the basis of the distinctive clinical, epidemiological, phenotypic features and genotypic features, $R$. slovaca was finally accepted as a separate taxonomic species (Sekeyova et al., 1998). The prevalence of $R$. slovaca in Slovakia has been continuously monitored, confirmed in D. marginatus, and in other ticks (Rehacek et al., 1976a; Spitalska and Kocianova, 


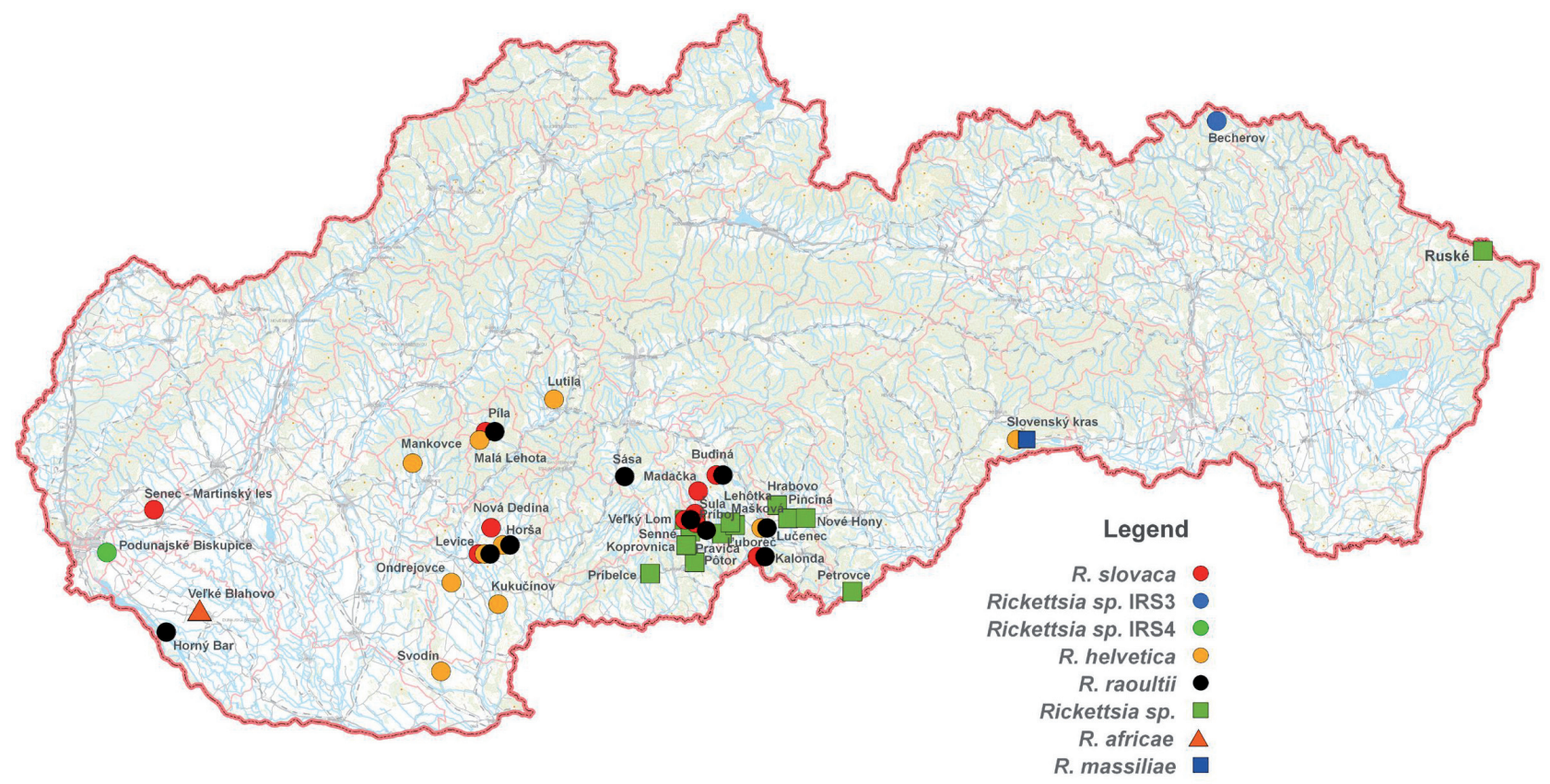

Fig. 7

Map of rickettsiae in Slovakia

2002; Spitalska et al., 2012). The role of dogs in the circulation of $R$. slovaca has been defined (Kovacova et al., 2006), and even contact with horses as a risk factor for dispersion of $R$. slovaca has recently been described (Lakos et al., 2012).

$R$. slovaca is a human pathogen. A variety of names have been attributed to the disease it causes e.g. scalp eschar and neck lymphadenopathy after tick bites (SENLAT) (Angelakis et al., 2010), tick-borne lymphadenopathy (TIBOLA) (Lakos, 1997, 2002; Lakos et al., 2012), or Dermacentor-borne necrosis erythema and lymphadenopathy (DEBONEL) (Ibarra et al., 2006; Oteo et al., 2004; Raoult et al., 1997a; Selmi et al., 2008). This illness commonly occurs in Slovakia (Sekeyova et al., 2012c).

A study of this bacterium is continuously being carried out. Boldiš et al. (2008) provided a detailed picture of the infection cycle of $R$. slovaca including ultrastructural changes within host cel. PCR-RFLP assay based on enzymatic digestion of a623 bp of sca4 gene with HaeIII was suggested as one of the best tools for fast differentiation of $R$. slovaca from other rickettsiae (Spitalska et al., 2008). Growth kinetics of R. slovaca in static (L929 and Vero cells) and dynamic (D. marginatus and I. ricinus ticks) cultivation systems have helped us better characterize the biological properties of this species (Boldis and Spitalska, 2010).

\subsubsection{Rickettsia raoultii}

Rickettsia sp. genotypes DnS14, DnS28, and RpA4, were first identified as new subspecies of the $R$. massiliae genogroup in 1999 (Roux et al., 1995). A few years later, a DNA gene sequenc- ing of glt $A$ and ompA genes extracted from $D$. nutallii ticks collected in Siberia, and Rh. pumilio ticks collected in Astrakhan, helped to confirm $R$. raoultii as a new species (Rydkina et al., 1999). Since then, it has been detected in Dermacentor ticks throughout Europe, the European part of Russia (Shpynov et al., 2001), Germany (Dautel et al., 2006), Portugal (Vitorino et al., 2007b), the Netherlands (Nijhof et al., 2007), France, Croatia (Mediannikov et al., 2008), Poland (Chmielewski et al., 2009), and Spain (Marquez, 2008). In Mongolia it was detected in D. nuttalli ticks (Speck et al., 2012). Rickettsia raoultii-like bacteria was found in Dermacentor spp. ticks in Tibet, China (Wang et al., 2012). The most recent isolate of its kind is available from Dutch D. reticulates ticks (Alberdi et al., 2012). A human case was recently reported in Poland (Switaj et al., 2012).

$R$. raoultii is commonly found in D. marginatus and D. reticulatus ticks collected in Slovakia, of which molecular evidence was provided (Boldis et al., 2008). The prevalence of $R$. raoultii was found to be from 9\% to 22-27\% (Spitalska et al., 2012), and an occurrence of the disease triggered by this bacteria confirmed (Sekeyova et al., 2012c). Infection with this agent appears to be less pathogenic in humans than with $R$. slovaca (Parola et al. 2009). Interestingly, this rickettsia has been proved to be resistant to rifampicin (Mediannikov et al., 2008).

\subsubsection{Rickettsia monacensis}

In 2000, two rickettsial strains: Rickettsia sp. "IRS3" and "IRS4" were detected in I. ricinus ticks collected in north eastern and south western Slovakia (Sekeyova et al., 2000, 
2003). Sequences of the $16 \mathrm{~S}$ rRNA, citrate synthase ( $g l t A)$ and outer membrane protein $r O m p A$ encoding genes of both strains were shown to be nearly identical but distinct from those of all other known rickettsiae. Phylogenetic analysis inferred from gltA and $16 \mathrm{~S}$ rDNA sequence comparisons showed that this rickettsial genotype is most closely related to $R$. helvetica. This rickettsia can be commonly found in $I$. ricinus ticks, in vegetation of Slovakia, as in other European countries, e.g. in Italy (Sanogo et al., 2003), Spain (Fernandez-Soto et al., 2004), Bulgaria (Christova et al., 2003), Serbia (Tomanovic et al., 2012). In 2002, it was isolated, characterized and named $R$. monacensis in Germany (Simser et al., 2002). It was confirmed to be frequently occurring in Germany (Schicht et al., 2012) and Switzerland (Lommano et al., 2012)in co-infections with other rickettsial species. It was found in ticks removed from humans in Turkey (Gargili et al., 2012), or those collected from domestic dogs in the Ukraine (Hamel et al., 2012). It was find not only in Europe, but also in China (Fernandez-Soto et al., 2004;Huang et al., 2006) and North Africa (Jado et al., 2007).

$R$. monacensis is a human pathogen, detected as a cause of Mediterranean spotted fever-like illness in Italy (Madeddu et al., 2012) and Spain (Jado et al., 2007). In addition to fever and flu-like symptoms, the inoculation eschar was identified only in an Italian patient (left calf) but generalized rash, including palms and soles, only in both Spanish patients. The patients recovered without sequelae with doxycycline treatment.

\subsubsection{Rickettsia helvetica}

$R$. helvetica was first isolated from $I$. ricinus ticks in Switzerland (Burgdorfer et al., 1979). It has been generally accepted that $I$. ricinus is the main vector of $R$. helvetica. However, D. reticulatus ticks were found to be infected with R. helvetica in Croatia (Dobec et al., 2009). Serosurveys have found antibodies reactive to $R$. helvetica in $1.9 \%-12.5 \%$ of the population and PCR positive cases were confirmed in France (Davoust et al., 2012), Italy (Corrain et al., 2012), Austria (Sonnleitner et al., 2012), Poland (Chmielewski et al., 2011) and Sweden (Nilsson et al., 2010). R. helvetica was also detected in Africa and Asia (Parola et al., 2005).

In Slovakia, $R$. helvetica was identified by molecular biology in $I$. ricinus ticks [adults captured from vegetation (Spitalska et al., 2008), collected from free-living green lizards (Vaclav et al., 2011), or nymphs picked from P. modularis birds (Spitalska et al., 2011)], and in roe deer (Stefanidesova et al., 2008). Human cases were confirmed (Sekeyova et al., 2012c), and the first isolation of $R$. helvetica yield from ticks collected in Slovakia has recently been provided (Sekeyova et al., 2012b). No human strain of $R$. helvetica exists worldwide.

\subsubsection{Rickettsia conorii conorii}

$R$. conorii conorii is responsible for the MSF, also known under various other names, as Boutonneuse fever. The disease is transmitted to humans by brown dog ticks $R$. sanguineus (Raoult et al., 1997a). MSF is widely distributed throughout the Mediterranean basin and the Middle East (Gilot et al., 1990; Raoult et al., 1986). R. sanguineus ticks rarely feed on people unless its preferred host (the domestic dog) is not available.

This kind of tick is not domestic in Slovakia however; the existence of sporadic intrusion of this tick into south parts however cannot be excluded. The presence of $R$. conorii conorii in Slovakia was confirmed by serological examination, in dogs $(3.1 \%)$ and in humans $(2.9 \%)$ (Kovacova et al., 2006). However, molecular evidence of the occurrence of $R$. conorii conorii in Slovakia is not available.

\subsubsection{Rickettsia africae}

$R$. africae, the etiologic agent of African tick bite fever (ATBF), was discovered twice: the first time isolated in 1930 by Pijper but unfortunately this isolate was lost and the second time in 1992 by the Raoult team from the blood of a 36-year-old Zimbabwean woman (Kelly et al., 1992a). However, the clinical signs of ATBF were described in 1911 in Mozambique and South Africa (McNaught, 1911). Numerous cases have been described recently, mainly in international travellers (Kernif et al., 2012; Socolovschi et al., 2012d). An epidemiologic success of the dispersion of this disease is due to various factors, including the increase of tourism, mode of attack (multiple at once), host-seeking behavior of its vector ticks, Amblyomma spp., and the elevated prevalence of $R$. africae in these ticks, with infection rates of up to $100 \%$ (Parola et al., 2001). This bacterium has been frequently identified in areas with warm climates, such as the West Indies, where it was found in Guadeloupe, Martinique, St Kitts and Nevis, and the Antigua islands (Parola et al., 2005). Cases in Europe are only occasionally introduced, sporadically described, mostly detected in travellers returning from Africa. No human case has ever been recorded in Slovakia however; $R$. africae was detected in Ceratophyllus garei flea collected from Reed warbler (Acrocephalus scirpaceus), a migrating bird captured upon arrival from Africa (Sekeyova et al., 2012a).

\subsubsection{Rickettsia spp.}

Unspecified types of Rickettsia spp. were found in nymph from the passerine bird, European robin Erithacus rubecula, ticks recovered from humans, or dogs, in the Carpathian region (Spitalska et al., 2006).

\section{Conclusion}

In recent decades, the identification and description of rickettsial species have increased dramatically from various arthropod species worldwide driven largely by the use of 
molecular techniques and cell culture. Some rickettsial species that were considered non-pathogenic for decades are now associated with infection of humans, such as $R$. slovaca isolated in 1968 in Slovakia (Brezina et al., 1969) and recognized as human a pathogen only in 1997 in France (Brezina et al., 1969) or R. monacensis detected in ticks in 2000 in Slovakia (Sekeyova et al., 2000) and recognized as a human pathogen in 2007 in Spain (Jado et al., 2007; Raoult et al., 1998b). Novel Rickettsia species of undetermined pathogenicity continue to be detected in or isolated around the world such as recently isolated Rickettsia sp. AvBat from Argas vespertilionis, bat ticks in Southern France (Socolovschi et al., 2012a). In addition, new discoveries such as the detection of rickettsial agents in mosquito vectors (Socolovschi et al., 2012b,c); the high level of rickettsial etiology in febrile patients in rural sub-Saharan Africa, Afganistan, or Nepal (Maina et al., 2012; Pradhan et al., 2012; Bailey et al., 2011); the possibility of the plant-mediated transmission route of endosymbiotic Rickettsia (Caspi-Fluger et al., 2012) open new issues in the rickettsial field. In the case of rickettsial projects in Slovakia, preparation and prevention are the main tasks for future. We would like to test other arthopod species and to follow up on human rickettsioses in Slovakia. The potential for bioterrorism through the deliberate release of an infectious agent in an area not previously affected adds a further dimension to the emergence of infectious disease and its control. Multidisciplinary research activities with focused goals that span over to international constellations of scientists are a reliable indication and warranty of bio safety prevention in Slovakia and Europe.

Acknowledgements. The authors are very grateful to Ludmila Hasíková and Gitka Benkovičová for the technical assistance in last decades of rickettsial studies provided in Slovakia. This study was financially supported by the projects VEGA Nos. 2/0061/13, 2/0193/12, 2/0031/11, 2/0142/10 from the Scientific Grant Agency of Ministry of Education and Slovak Academy of Sciences.

\section{References}

Alberdi MP, Nijhof AM, Jongejan F, Bell-Sakyi L, Ticks Tick Borne Dis. 2012.

Amano KI, Williams JC, Dasch GA, Infect. Immun. 66, 923-926, 1998.

Andersson JO, Andersson SG, Curr. Opin. Genet. Dev. 9, 664-671, 1999. http://dx.doi.org/10.1016/S0959437X(99)00024-6

Andersson JO, Andersson SG, Res. Microbiol. 151, 143-150, 2000. http://dx.doi.org/10.1016/S0923-2508(00)00116-9

Andersson SG, Kurland CG, Trends Microbiol. 6, 263-268, 1998. http://dx.doi.org/10.1016/S0966-842X(98)01312-2

Angelakis E, Pulcini C, Waton J, Imbert P, Socolovschi C, Edouard S, Dellamonica P, Raoult D, Clin. Infect. Dis. 50, 549-551, 2010. http://dx.doi.org/10.1086/650172
Angelakis E, Richet H, Rolain JM, La SB, Raoult D, PLoS. Negl. Trop. Dis. 6, e1540, 2012.

Azad AF, Annu. Rev. Entomol. 35, 553-569, 1990. http://dx.doi. org/10.1146/annurev.en.35.010190.003005

Azad AF, Clin. Infect. Dis. 45, Suppl 1, S52-S55, 2007. http://dx.doi. org/10.1086/518147

Bacellar F, Regnery RL, Nuncio MS, Filipe AR, Epidemiol. Infect. 114, 169-178, 1995. http://dx.doi.org/10.1017/ S095026880005202X

Bailey MS, Trinick TR, Dunbar JA, Hatch R, Osborne JC, Brooks TJ, Green AD, Afghanistan. J. R. Army Med. Corps. 157, 150155, 2011. http://dx.doi.org/10.1136/jramc-157-02-05

Balayeva NM, Demkin VV, Rydkina EB, Ignatovich VF, Artemiev MI, Lichoded LY, Genig VA, Acta Virol. 37, 475-483, 1993.

Balraj P, El KK, Vestris G, Espinosa L, Raoult D, Renesto P, PLoS One. 3, e2582, 2008. http://dx.doi.org/10.1371/journal. pone. 0002582

Beati L, Finidori JP, Raoult D, Am. J. Trop. Med. Hyg. 48, 257-268, 1993a.

Beati L, Humair PF, Aeschlimann A, Raoult D, Am. J. Trop. Med. Hyg, 51, 138-148, 1994.

Beati L, Peter O, Burgdorfer W, Aeschlimann A, Raoult D, Int. J. Syst. Bacteriol. 43, 521-526, 1993b. http://dx.doi. org/10.1099/00207713-43-3-521

Bechah Y, Capo C, Mege JL, Raoult D, Lancet Infect. Dis. 8, 417-426, 2008a. http://dx.doi.org/10.1016/S1473-3099(08)701506

Bechah Y, Capo C, Mege JL, Raoult D, Future Microbiol. 3, 223-236, 2008b. http://dx.doi.org/10.2217/17460913.3.2.223

Bechah Y, Socolovschi C, Raoult D, Emerg. Infect. Dis. 17, 83-86, 2011. http://dx.doi.org/10.3201/eid1701.100854

Bella-Cueto F, Font-Creus B, Segura-Porta F, Espejo-Arenas E, Lopez-Pares P, Munoz-Espin T, J. Infect. Dis. 155, 10561058, 1987. http://dx.doi.org/10.1093/infdis/155.5.1056

Beltran E, Herrero H, Antimicrob. Agents Chemother. 36, 13421344, 1992. http://dx.doi.org/10.1128/AAC.36.6.1342

Birtles RJ, Harrison TG, Saunders NA, Molyneux DH, Int. J. Syst. Bacteriol. 45, 1-8, 1995. http://dx.doi.org/10.1099/00207713$\underline{45-1-1}$

Blanc G, Ogata H, Robert C, Audic S, Suhre K, Vestris G, Claverie JM, Raoult D, PLoS Genet. 3, e14, 2007. http://dx.doi. org/10.1371/journal.pgen.0030014

Blanco JR, Oteo JA, Ann. N. Y. Acad. Sci. 1078, 26-33, 2006. http:// dx.doi.org/10.1196/annals.1374.003

Boldis V, Kocianova E, Strus J, Tusek-Znidaric M, Sparagano OA, Stefanidesova K, Spitalska E, Ann. N. Y. Acad. Sci. 1149, 281-285, 2008. http://dx.doi.org/10.1196/annals. 1428.090

Boldis V, Spitalska E, Exp. Appl. Acarol. 50, 353-359, 2010. http:// dx.doi.org/10.1007/s10493-009-9322-7

Boldis V, Strus J, Kocianova E, Tusek-Znidaric M, Stefanidesova K, Spitalska E, Folia Microbiol. 54, 130-136, 2009. http:// dx.doi.org/10.1007/s12223-009-0019-4

Botelho-Nevers E, Edouard S, Leroy Q, Raoult D, J. Antimicrob. Chemother. 67, 1677-1682, 2012. http://dx.doi. org/10.1093/jac/dks089 
Botelho-Nevers E, Raoult D, Eur. J. Clin. Microbiol. Infect. Dis. 30, 1139-1150, 2011. http://dx.doi.org/10.1007/s10096011-1208-Z

Botelho-Nevers E, Rovery C, Richet H, Raoult D, J. Antimicrob. Chemother. 66, 1821-1830, 2011. http://dx.doi. org/10.1093/jac/dkr218

Bozeman FM, Masiello SA, Williams MS, Elisberg BL, Nature. 255, 545-547, 1975. http://dx.doi.org/10.1038/255545a0

Brezina R, Rehacek J, Ac P, Majerska M, Acta Virol. 13, 142-145, 1969.

Brouqui P, Bacellar F, Baranton G, Birtles RJ, Bjoersdorff A, Blanco JR, Caruso G, Cinco M, Fournier PE, Francavilla E, Jensenius M, Kazar J, Laferl H, Lakos A, Lotric FS, Maurin M, Oteo JA, Parola P, Perez-Eid C, Peter O, Postic D, Raoult D, Tellez A, Tselentis Y, Wilske B, Clin. Microbiol. Infect. 10, 1108-1132, 2004. http://dx.doi. org/10.1111/j.1469-0691.2004.01019.x

Brouqui P, Parola P, Fournier PE, Raoult D, FEMS Immunol. Med. Microbiol. 49, 2-12, 2007. http://dx.doi.org/10.1111/ j.1574-695X.2006.00138.x

Bullova E, Lukan M, Stanko M, Petko B, Vet. Parasitol. 165, 357-360, 2009. http://dx.doi.org/10.1016/j.vetpar.2009.07.023

Burgdorfer W, Aeschlimann A, Peter O, Hayes SF, Philip RN, Acta Trop. 36, 357-367, 1979.

Burgdorfer W, Friedhoff KT, Lancaster JL, Jr., Bull. World Health Organ. 35, 149-153, 1966.

Cardwell MM, Martinez JJ, Infect. Immun. 77, 5272-5280, 2009. http://dx.doi.org/10.1128/IAI.00201-09

Cascio A, Di LC, D‘Angelo M, Iaria C, Scarlata F, Titone L, Campisi G, Antimicrob. Agents Chemother. 48, 2739-2741, 2004. http://dx.doi.org/10.1128/AAC.48.7.2739-2741.2004

Caspi-Fluger A, Inbar M, Mozes-Daube N, Katzir N, Portnoy V, Belausov E, Hunter MS, Zchori-Fein E, Proc. Biol. Sci. 279, 17911796, 2012. http://dx.doi.org/10.1098/rspb.2011.2095

Cerny V, Folia Parasitol. 19, 87-92, 1972.

Chan YG, Cardwell MM, Hermanas TM, Uchiyama T, Martinez JJ, Cell Microbiol. 11, 629-644, 2009. http://dx.doi. org/10.1111/j.1462-5822.2008.01279.x

Chmielewski T, Andrzejewski K, Maczka I, Fiecek B, Radlinska M, Tylewska-Wierzbanowska S, Przegl. Epidemiol. 65, 577-581, 2011.

Chmielewski T, Podsiadly E, Karbowiak G, Tylewska-Wierzbanowska S, Emerg. Infect. Dis. 15, 486-488, 2009. http:// dx.doi.org/10.3201/eid1503.080711

Christova I, Van De Pol J, Yazar S, Velo E, Schouls L, Eur J Clin Microbiol Infect Dis., 22, 535-542, 2003. http://dx.doi. org/10.1007/s10096-003-0988-1

Civen R, Ngo V, Clin. Infect. Dis. 46, 913-918, 2008. http://dx.doi. org $/ 10.1086 / 527443$

Coolbaugh JC, Progar JJ, Weiss E, Infect. Immun. 14, 298-305, 1976.

Corrain R, Drigo M, Fenati M, Menandro ML, Mondin A, Pasotto D, Martini M, Zoonoses Public. Health. 59, 468-476, 2012. http://dx.doi.org/10.1111/j.1863-2378.2012.01490.x

da Rocha Lima, H. Munch. Med. Wochenschr. 1, 33, 1917.

Darby AC, Cho NH, Fuxelius HH, Westberg J, Andersson SG, Trends Genet. 23, 511-520, 2007. http://dx.doi. org/10.1016/j.tig.2007.08.002
Dautel H, Dippel C, Oehme R, Hartelt K, Schettler E, Int. J. Med. Microbiol. 296 Suppl 40, 149-156, 2006.

http://dx.doi.org/10.1016/j.ijmm.2006.01.013. Davoust B, Socolovschi C, Revelli P, Gibert P, Marie JL, Raoult D, Parola P, Ticks Tick Borne Dis. 2012.

Dobec M, Golubic D, Punda-Polic V, Kaeppeli F, Sievers M, Emerg. Infect. Dis. 15, 98-100, 2009. http://dx.doi.org/10.3201/ eid1501.080815

Ellison DW, Clark TR, Sturdevant DE, Virtaneva K, Porcella SF, Hackstadt T, Infect. Immun. 76, 542-550, 2008. http:// dx.doi.org/10.1128/IAI.00952-07

Eremeeva ME, Dasch GA, Silverman DJ Clin. Diagn. Lab. Immunol. 8, 788-796, 2001.

Faucher JF, Socolovschi C, Aubry C, Chirouze C, Hustache-Mathieu L, Raoult D, Hoen B, Emerg. Infect. Dis. 18, 171-172, 2012. http://dx.doi.org/10.3201/eid1801.111057

Fenollar F, Raoult D, Clin. Diagn. Lab. Immunol. 6, 483-488. (1999)

Fernandez-Soto P, Perez-Sanchez R, Encinas-Grandes A, Sanz RA, Eur. J. Clin. Microbiol. Infect. Dis, 23, 648-649, 2004. http://dx.doi.org/10.1007/s10096-004-1184-7

Fodorova M, Vadovic P, Toman R, Acta Virol. 55, 31-44, 2011. http://dx.doi.org/10.4149/av 2011 0131

Fournier PE, Dumler JS, Greub G, Zhang J, Wu Y, Raoult D, J. Clin. Microbiol. 41, 5456-5465, 2003. http://dx.doi. org/10.1128/JCM.41.12.5456-5465.2003

Fournier PE, El KK, Leroy Q, Robert C, Giumelli B, Renesto P, Socolovschi C, Parola P, Audic S, Raoult D, BMC Genomics. 10, 166, 2009. http://dx.doi.org/10.1186/1471-2164-10-166

Fournier PE, Jensenius M, Laferl H, Vene S, Raoult D, Clin Diagn Lab Immunol. 9, 324-328, 2002.

Fournier PE, Raoult D, BMC Microbiol. 7, 72, 2007. http://dx.doi. org/10.1186/1471-2180-7-72

Fournier PE, Roux V, and Raoult D, Int. J. Syst. Bacteriol. $48 \mathrm{Pt}$ 3, 839-849, 1998. http://dx.doi.org/10.1099/0020771348-3-839

Fournier PE, Zhu Y, Yu X, Raoult D, Ann. N. Y. Acad. Sci. 1078, 597-606, 2006. http://dx.doi.org/10.1196/annals. 1374.120

Gargili A, Palomar AM, Midilli K, Portillo A, Kar S, Oteo JA, Vector Borne Zoonotic Dis. 12, 938-941, 2012. http://dx.doi. org/10.1089/vbz.2012.0996

Gilot B, Laforge ML, Pichot J, Raoult D, Eur. J. Epidemiol. 6, 357362, 1990. http://dx.doi.org/10.1007/BF00151708

Gimenez DF, Stain Technol. 39, 135-140, 1964.

Ham H, Sreelatha A, Orth K, Nat. Rev. Microbiol. 9, 635-646, 2011. http://dx.doi.org/10.1038/nrmicro2602

Hamel D, Silaghi C, Zapadynska S, Kudrin A, Pfister K, Ticks Tick Borne Dis. doi: 10.1016/j.ttbdis.2012.08.005., 2012.http:// dx.doi.org/10.1016/j.ttbdis.2012.08.005

Heinzen RA, Ann. N. Y. Acad. Sci. 990, 535-547, 2003. http://dx.doi. org/10.1111/j.1749-6632.2003.tb07424.x

Hirunkanokpun S, Thepparit C, Foil LD, Macaluso KR, Mol. Ecol. 20, 4577-4586, 2011. http://dx.doi.org/10.1111/j.1365294X.2011.05289.X

Houhamdi L, Fournier PE, Fang R, Lepidi H, Raoult D, J. Infect. Dis. 186, 1639-1646, 2002. http://dx.doi.org/10.1086/345373 
Huang HN, Ding Z, He J, Wu XM, Jiang BG, Gao Y, Chu CY, Zhan L, Zhao QM, Wang YF, Cao WC, Zhonghua Liu Xing Bing Xue Za Zhi. 27, 379-383, 2006.

Ibarra V, Oteo JA, Portillo A, Santibanez S, Blanco JR, Metola L, Eiros JM, Perez-Martinez L, Sanz M, Ann. N. Y. Acad. Sci. 1078, 206-214, 2006. http://dx.doi.org/10.1196/annals. 1374.040

Irons FJV, Bohls SW, Thurman DC, McGregor T, Am. J. Trop. Med. 24, 359-362, 1944.

Jado I, Oteo JA, Aldamiz M, Gil H, Escudero R, Ibarra V, Portu J, Portillo A, Lezaun MJ, Garcia-Amil C, RodriguezMoreno I, Anda P, Emerg. Infect. Dis. 13, 1405-1407, 2007. http://dx.doi.org/10.3201/eid1309.060186

Jensenius M, Fournier PE, Raoult D, Clin. Infect. Dis. 39, 1493-1499, 2004a. http://dx.doi.org/10.1086/425365

Jensenius M, Fournier PE, Vene S, Ringertz SH, Myrvang B, Raoult D, Clin. Diagn. Lab. Immunol. 11, 786-788, $2004 \mathrm{~b}$.

Kelly P, Matthewman L, Beati L, Raoult D, Mason P, Dreary M, Makombe R, Lancet 340, 982-983, 1992a. http://dx.doi. org/10.1016/0140-6736(92)92878-I

Kelly RW, Leask R, Calder AA, Lancet 339, 776-777, 1992b. http:// dx.doi.org/10.1016/0140-6736(92)91896-G

Kernif T, Djerbouh A, Mediannikov O, Ayach B, Rolain JM, Raoult D, Parola P, Bitam I, Ticks Tick Borne Dis. 2012

Kleba B, Clark TR, Lutter EI, Ellison DW, Hackstadt T, Infect. Immun. 78, 2240-2247, 2010. http://dx.doi.org/10.1128/ IAI.00100-10

Kocianova E, Kozuch O, Folia Parasitol. 35, 175-180, 1988.

Kovacova E, Kazar J, Clin. Lab. 46, 239-245, 2000.

Kovacova E, Sekeyova Z, Travnicek M, Bhide MR, Mardzinova S, Curlik J, Spanelova D, Ann. N. Y. Acad. Sci. 1078, 587-589, 2006. http://dx.doi.org/10.1196/annals.1374.117

La Scola B, Raoult D, J. Clin. Microbiol. 35, 2715-2727, 1997.

Lakos A, Lancet. 350, 1006, 1997. http://dx.doi.org/10.1016/S01406736(05)64072-X

Lakos A Wien Klin Wochenschr., 114, 648-654, 2002.

Lakos A, Korosi A, Foldvari G, Wien Klin. Wochenschr. 124, 611-617, 2012. http://dx.doi.org/10.1007/s00508-012$\underline{0217-y}$

Le Chuiton F, Berge C, Ennaneac HJ. Bull. Soc. Pathol. Exot. 28, 685-688, 1935.

Lepine P, Lorando N, Bull. Soc. Pathol. Exot. 33, 46, 1935.

Leshem E, Meltzer E, Schwartz E, Curr. Opin. Infect. Dis. 24, 457-463, 2011. http://dx.doi.org/10.1097/QCO.0b013e32834albd2

Li H, Walker DH, Microb. Pathog. 24, 289-298, 1998. http://dx.doi. org/10.1006/mpat.1997.0197

Lochary ME, Lockhart PB, Williams WT, Jr., Pediatr. Infect. Dis. J. 17, 429-431, 1998. http://dx.doi.org/10.1097/00006454199805000-00019

Lommano E, Bertaiola L, Dupasquier C, Gern L, Appl. Environ. Microbiol. 78, 4606-4612, 2012. http://dx.doi.org/10.1128/ AEM.07961-11

Lutwick LI, Lancet 357, 1198-1200, 2001. http://dx.doi.org/10.1016/ S0140-6736(00)04339-7

Madeddu G, Mancini F, Caddeo A, Ciervo A, Babudieri S, Maida I, Fiori ML, Rezza G, Mura MS, Emer. Infect. Dis. 18, 702704, 2012. http://dx.doi.org/10.3201/eid1804.111583
Maina AN, Knobel DL, Jiang J, Halliday J, Feikin DR, Cleaveland S, Ng'ang`‘ Z, Junghae M, Breiman RF, Richards AL, Njenga MK, Emer. Infect. Dis. 18, 328-331, 2012. http://dx.doi. org/10.3201/eid1802.111372

Manor E, Ighbarieh J, Sarov B, Kassis I, Regnery R, J. Clin. Microbiol. 30, 2653-2656, 1992.

Marquez FJ, Exp. Appl. Acarol. 45, 185-194, 2008. http://dx.doi. org/10.1007/s10493-008-9181-7

McNaught, J. M. Army Med. Corps. 16, 505, 1911.

Mediannikov O, Matsumoto K, Samoylenko I, Drancourt M, Roux V, Rydkina E, Davoust B, Tarasevich I, Brouqui P, Fournier PE, Int. J. Syst. Evol. Microbiol. 58, 1635-1639, 2008. http://dx.doi.org/10.1099/ijs.0.64952-0

Merhej V, Raoult D, Biol. Rev. Camb. Philos. Soc. 86, 379-405, 2011. http://dx.doi.org/10.1111/j.1469-185X.2010.00151.x

Merhej V, Royer-Carenzi M, Pontarotti P, Raoult D, Biol. Direct. 4, 13, 2009. http://dx.doi.org/10.1186/1745-6150-4-13

Mouffok N, Socolovschi C, Benabdellah A, Renvoise A, Parola P, Raoult D, Emerg. Infect. Dis. 17, 1968-1969, 2011. http:// dx.doi.org/10.3201/eid1710.110332

Mura A, Masala G, Tola S, Satta G, Fois F, Piras P, Rolain JM, Raoult D, Parola P, Clin. Microbiol. Infect. 14, 1028-1033, 2008. http://dx.doi.org/10.1111/j.1469-0691.2008.02082.x

Nijhof AM, Bodaan C, Postigo M, Nieuwenhuijs H, Opsteegh M, Franssen L, Jebbink F, Jongejan F, Vector Borne Zoonotic Dis. 7, 585-595, 2007. http://dx.doi.org/10.1089/ vbz.2007.0130

Nosek J, Folia Parasitol. 19, 93-102, 1972.

Nosek J, Grulich I, Bull. World Health Organ. 36 Suppl, 31-47, 1967.

Ogata H, Audic S, Renesto-Audiffren P, Fournier PE, Barbe V, Samson D, Roux V, Cossart P, Weissenbach J, Claverie JM, Raoult D, Science 293, 2093-2098, 2001. http://dx.doi. org/10.1126/science.1061471

Olano JP, Ann. N. Y. Acad. Sci. 1063, 187-196, 2005. http://dx.doi. org/10.1196/annals.1355.031

Oteo JA, Ibarra V, Blanco JR, Martinez dA, V, Marquez FJ, Portillo A, Raoult D, Anda P, Clin. Microbiol. Infect. 10, 327-331, 2004. http://dx.doi.org/10.1111/j.1198743X.2004.00782.X

Ozturk MK, Gunes T, Kose M, Coker C, Radulovic S, Emerg. Infect. Dis. 9, 1498-1499, 2003. http://dx.doi.org/10.3201/ eid0911.030224

Palmer GH, Vet. Immunol. Immunopathol. 85, 1-8, 2002. http:// dx.doi.org/10.1016/S0165-2427(01)00415-9

Park H, Lee JH, Gouin E, Cossart P, Izard T, J. Biol. Chem. 286, 35096-35103, 2011. http://dx.doi.org/10.1074/jbc. M111.263855

Parola P, Clin. Microbiol. Infect. 17, 996-1000, 2011. http://dx.doi org/10.1111/j.1469-0691.2011.03516.x

Parola P, Inokuma H, Camicas JL, Brouqui P, Raoult D, Emerg. Infect. Dis.7, 1014-1017, 2001. http://dx.doi.org/10.3201/ eid0706.010616

Parola P, Paddock CD, Raoult D, Clin. Microbiol. Rev. 18, 719756, 2005. http://dx.doi.org/10.1128/CMR.18.4.719$\underline{756.2005}$

Parola P, Raoult D, Clin. Microbiol. Infec., 7, 80-83, 2001. http:// dx.doi.org/10.1046/j.1469-0691.2001.00200.x 
Patterson KD, Med Hist. 37, 361-381, 1993. http://dx.doi. org/10.1017/S0025727300058725

Petko B, Cesk. Epidemiol. Mikrobiol. Imunol. 42, 190-191, 1993.

Philip C.B, Public Health Rep. 74, 595-600, 1959. http://dx.doi. org/10.2307/4590519

Pradhan R, Shrestha U, Gautam SC, Thorson S, Shrestha K, Yadav BK, Kelly DF, Adhikari N, Pollard AJ, Murdoch DR, PLoS One 7, e47531, 2012. http://dx.doi.org/10.1371/journal. pone. 0047531

Price WH, J. Bacteriol. 69, 106-107, 1955.

Radulovic S, Feng HM, Morovic M, Djelalija B, Popov V, CrocquetValdes P, Walker DH, Clin. Infect. Dis. 22, 216-220, 1996. http://dx.doi.org/10.1093/clinids/22.2.216

Raoult D, Maurin M, In Rickettsia species. Yu VL, Merigan TC, Barriere SE, Baltimore, USA, Williams \& Wilkins, pp. 568-574, 1998.

Raoult D, Maurin M, In Yu VL, Weber R, Raoult D, New York, Apple Trees Production, LLC, pp. 913-921, 2002.

Raoult D, Dasch GA, FEMS Immunol. Med. Microbiol. 11, 1318, 1995. http://dx.doi.org/10.1111/j.1574-695X.1995. tb00073.x

Raoult D, Fournier PE, Eremeeva M, Graves S, Kelly PJ, Oteo JA, Sekeyova Z, Tamura A, Tarasevich I, Zhang L, Ann. N. Y. Acad. Sci. 1063, 1-12, 2005. http://dx.doi.org/10.1196/ annals. 1355.002

Raoult D, Fournier PE, Fenollar F, Jensenius M, Prioe T, de Pina JJ, Caruso G, Jones N, Laferl H, Rosenblatt JE, Marrie TJ, N. Engl. J. Med. 344, 1504-1510, 2001. http://dx.doi. org/10.1056/NEJM200105173442003

Raoult D, Ndihokubwayo JB, Tissot-Dupont H, Roux V, Faugere B, Abegbinni R, Birtles RJ, Lancet 352, 353-358, 1998. http:// dx.doi.org/10.1016/S0140-6736(97)12433-3

Raoult D, Roux V, Clin. Microbiol. Rev. 10, 694-719, 1997a.

Raoult D, Roux V, Clin. Infect. Dis. 29, 888-911, 1999. http://dx.doi. org/10.1086/520454

Raoult D, Roux V, Ndihokubwayo JB, Bise G, Baudon D, Marte G, Birtles R, Emerg. Infect. Dis. 3, 357-360, 1997. http:// dx.doi.org/10.3201/eid0303.970313

Raoult D, Weiller PJ, Chagnon A, Chaudet H, Gallais H, Casanova P, Am. J. Trop. Med. Hyg. 35, 845-850, 1986.

Raoult D, Woodward T, Dumler JS, Infect. Dis. Clin. North. Am. 18, 127-140, 2004. http://dx.doi.org/10.1016/S08915520(03)00093-X

Rees HB, Jr., Weiss E, J. Bacteriol. 95, 389-396, 1968.

Rehacek J, Tarasevich I, Slovak Academy of Sciences, Bratislava, Slovakia, Veda, pp. 1-145, 1988.

Rehacek J, Kovacova E, Kovac P, Folia Parasitol. 23, 69-73, 1976a.

Rehacek J, Kovacova E, Lisak V, Rumin W, Folia Parasitol. 37, 285-286, 1990.

Rehacek J, Palanova A, Zupancicova M, Urvolgyi J, Kovacova E, Jarabek L, Brezina R, J. Hyg. Epidemiol. Microbiol. Immunol. 19, 105-115, 1975a.

Rehacek J, Urvolgyi J, Kocianova E, Sekeyova Z, Vavrekova M, Kovacova E, Eur. J. Epidemiol. 7, 299-303, 1991. http:// dx.doi.org/10.1007/BF00145682

Rehacek J, Urvolgyi J, Kovacova E, Acta Virol. 21, 431-438, 1977.
Rehacek J, Zupancicova M, Kovacova E, Urvolgyi J, Brezina R, J. Hyg. Epidemiol. Microbiol. Immunol. 19, 329-339, $1975 b$.

Rehacek J, Zupancicova M, Kovacova E, Urvolgyi J, Brezina R, J. Hyg. Epidemiol. Microbiol. Immunol. 21, 306-313, 1976b.

Reif KE, Macaluso KR, J. Med. Entomol. 46, 723-736, 2009. http:// dx.doi.org/10.1603/033.046.0402

Renesto P, Dehoux P, Gouin E, Touqui L, Cossart P, Raoult D, J. Infect. Dis. 188, 1276-1283, 2003. http://dx.doi. org/10.1086/379080

Renvoise A, Merhej V, Georgiades K, Raoult D, Trends Mol. Med. 17, 573-583, 2011. http://dx.doi.org/10.1016/j. molmed.2011.05.009

Ricketts HT, Wilder RM, JAMA. 54, 463-467, 1910. http://dx.doi. org/10.1001/jama.1910.925503200090020

Rolain JM, Jensenius M, Raoult D, Curr. Opin. Infect. Dis. 17, 433-437, 2004. http://dx.doi.org/10.1097/00001432200410000-00008

Rolain JM, Maurin M, Vestris G, Raoult D, Antimicrob. Agents. Chemother. 42, 1537-1541, 1998.

Rolain JM, Raoult D, Ann. N. Y. Acad. Sci. 1063, 222-230, 2005. http://dx.doi.org/10.1196/annals.1355.035

Roux V, Bergoin M, Lamaze N, Raoult D, Int. J. Syst. Bacteriol. 47, 1255-1257, 1997a.

http://dx.doi.org/10.1099/00207713-47-4-1255

Roux V, Raoult D, Res. Microbiol. 146, 385-396, 1995. http://dx.doi. org/10.1016/0923-2508(96)80284-1

Roux V, Raoult D, Int. J. Syst. Evol. Microbiol. 50 Pt 4, 1449-1455, 2000. http://dx.doi.org/10.1099/00207713-50-4-1449

Roux V, Rydkina E, Eremeeva M, Raoult D, Int. J. Syst. Bacteriol. 47, 252-261, 1997b. http://dx.doi.org/10.1099/0020771347-2-252

Rydkina E, Roux V, Rudakov N, Gafarova M, Tarasevich I, Raoult D, Emerg. Infect. Dis. 5, 811-814, 1999. http://dx.doi. org/10.3201/eid0506.990612

Sanogo YO, Parola P, Shpynov S, Camicas JL, Brouqui P, Caruso G, Raoult D, Ann. N. Y. Acad. Sci. 990, 182-190, 2003. http://dx.doi.org/10.1111/j.1749-6632.2003. tb07360.x

Schicht S, Schnieder T, Strube C, J. Med. Entomol. 49, 766-771, 2012. http://dx.doi.org/10.1603/ME11204

Schriefer ME, Sacci JB, Jr., Taylor JP, Higgins JA, Azad AF, J. Med. Entomol. 31, 681-685, 1994.

Schriefer ME, Azad AF, In Sonenshine DE, Mather TN, New York, USA, Oxford University Press, pp. 314-326, 1994.

Sekeyova Z, Fournier PE, Rehacek J, Raoult D, J. Med. Entomol. 37, 707713, 2000. http://dx.doi.org/10.1603/0022-2585-37.5.707

Sekeyova Z, Kovacova E, Fournier PE, Raoult D, Ann. N. Y. Acad. Sci. 990, 54-56, 2003. http://dx.doi. org/10.1111/j.1749-6632.2003.tb07336.x

Sekeyova Z, Mediannikov O, Roux V, Subramanian G, Spitalska E, Kristofik J, Darolova A, Raoult D, Vector Borne Zoonotic Dis. 12, 539-543, 2012a. http://dx.doi.org/10.1089/ vbz.2011.0645

Sekeyova Z, Mediannikov O, Subramanian G, Kowalczewska M, Quevedo-Diaz M, Kocianova E, Raoult D, Acta 
Virol. 56, 247-252, 2012b. http://dx.doi.org/10.4149/ av $2012 \quad 03 \quad 247$

Sekeyova Z, Roux V, Raoult D, Int. J. Syst. Evol. Microbiol. 51, 1353-1360, 2001

Sekeyova Z, Roux V, Xu W, Rehacek J, Raoult D, Int. J. Syst. Bacteriol. 48, 1455-1462, 1998. http://dx.doi.org/10.1099/0020771348-4-1455

Sekeyova Z, Subramanian G, Mediannikov O, Diaz MQ, Nyitray A, Blaskovicova H, Raoult D, FEMS Immunol. Med. Microbiol. 64, 82-91, 2012c. http://dx.doi.org/10.1111/j.1574695X.2011.00907.X

Selmi M, Bertolotti L, Tomassone L, Mannelli A, Emerg. Infect. Dis. 14, 817-820, 2008. http://dx.doi.org/10.3201/ eid1405.070976

Shpynov S, Parola P, Rudakov N, Samoilenko I, Tankibaev M, Tarasevich I, Raoult D, Eur. J. Clin. Microbiol. Infect. Dis. 20, 903-905, 2001. http://dx.doi.org/10.1007/s10096001-0638-4

Silverman DJ, Eur. J. Epidemiol. 7, 200-206, 1991. http://dx.doi. org/10.1007/BF00145667

Silverman DJ, Wisseman CL, Jr., Infect. Immun. 21, 1020-1023, 1978.

Silverman DJ, Wisseman CL, Jr., Waddell AD, Jones M, Infect. Immun. 22, 233-246, 1978a.

Silverman DN, Tu C, Wynns GC, J. Biol. Chem. 253, 2563-2567, 1978b.

Simser JA, Palmer AT, Fingerle V, Wilske B, Kurtti TJ, Munderloh UG, Appl. Environ. Microbiol. 68, 4559-4566, 2002. http://dx.doi.org/10.1128/AEM.68.9.4559-4566.2002

Socolovschi C, Kernif T, Raoult D, Parola P, Emerg. Infect. Dis.18, 1966-1975, 2012a. http://dx.doi.org/10.3201/ eid1812.111237

Socolovschi C, Pages F, Ndiath MO, Ratmanov P, Raoult D, PLoS One. 7, e48254, 2012b. http://dx.doi.org/10.1371/journal. pone. 0048254

Socolovschi C, Pages F, Raoult D, Emerg. Infect. Dis. 18, 1687-1689, 2012c. http://dx.doi.org/10.3201/eid1810.120178

Socolovschi C, Renvoise A, Brouqui P, Parola P, Raoult D, Ticks Tick Borne Dis. 3, 361-363, 2012d. http://dx.doi.org/10.1016/j. ttbdis.2012.10.018

Sonnleitner ST, Simeoni J, Lang S, Dobler G, Speck S, Zelger R, Schennach H, Lass-Florl C, Walder G, Zoonoses Public Health, 2012.

Speck S, Derschum H, Damdindorj T, Dashdavaa O, Jiang J, Kaysser P, Jigjav B, Nyamdorj E, Baatar U, Munkhbat E, Choijilsuren $\mathrm{O}$, Gerelchuluun O, Romer A, Richards AL, Kiefer D, Scholz H, Wolfel R, Zoller L, Dobler G, Essbauer S, Ticks Tick Borne Dis. 3, 227-231, 2012. http://dx.doi. org/10.1016/j.ttbdis.2012.04.001

Spitalska E, Boldis V, Kostanova Z, Kocianova E, Stefanidesova K, Acta Virol. 52, 175-179, 2008.

Spitalska E, Kocianova E, Acta Virol. 46, 49-50, 2002.

Spitalska E, Literak I, Kocianova E, Taragel'ova V, Vector Borne Zoonotic Dis. 11, 1235-1241, 2011. http://dx.doi. org/10.1089/vbz.2010.0210

Spitalska E, Literak I, Sparagano OA, Golovchenko M, Kocianova E, Wien Klin. Wochenschr. 118, 759-764, 2006. http:// dx.doi.org/10.1007/s00508-006-0729-4
Spitalska E, Stefanidesova K, Kocianova E, Boldis V, Exp. Appl. Acarol. 2012

Stanko M, Krasnov BR, Morand S, J. Anim. Ecol. 75, 575-583, 2006. http://dx.doi.org/10.1111/j.1365-2656.2006.01080.x

Stefanidesova K, Kocianova E, Boldis V, Kostanova Z, Kanka P, Spitalska E, Eur. J. Wildl. Res. 54, 519-524, 2008. http:// dx.doi.org/10.1007/s10344-007-0161-8

Stein A, Purgus R, Olmer M, Raoult D, Lancet 353, 1936, 1999.

Switaj K, Chmielewski T, Borkowski P, Tylewska-Wierzbanowska S, Olszynska-Krowicka M, Przegl. Epidemiol. 66, 347350, 2012.

Tamura A, Ohashi N, Urakami H, Miyamura S, Int. J. Syst. Bacteriol. 45, 589-591, 1995. http://dx.doi.org/10.1099/00207713$\underline{45-3-589}$

Tarasevich IV, Makarova VA, Fetisova NF, Stepanov AV, Miskarova ED, Raoult D, Eur. J. Epidemiol. 7, 294-298, 1991. http:// dx.doi.org/10.1007/BF00145681

Teysseire N, Boudier JA, Raoult D, Infect. Immun. 63, 366-374, 1995.

Tian ZC, Liu GY, Shen H, Xie JR, Luo J, Tian MY, Parasit. Vectors $5,19,2012$.

http://dx.doi.org/10.1186/1756-3305-5-19

Tomanovic S, Chochlakis D, Radulovic Z, Milutinovic M, Cakic S, Mihaljica D, Tselentis Y, Psaroulaki A, Exp. Appl. Acarol. 2012.

Traub R, Wisseman CL, Trop. Dis. Bull. 75, 237-317, 1978.

Turcinov D, Kuzman I, Herendic B, Antimicrob. Agents. Chemother. 44, 1737-1738, 2000. http://dx.doi.org/10.1128/ AAC.44.6.1737-1738.2000

Turcinov D, Kuzman I, Puljiz I, Lijec Vjesn., 124, 293-296, 2002.

Tyeryar FJ, Jr., Weiss E, Millar DB, Bozeman FM, Ormsbee RA, Science. 180, 415-417, 1973. http://dx.doi.org/10.1126/ science.180.4084.415

Urvolgyi J, Brezina R, In Proceedings of the 2nd International Symposium on Rickettsiae and Rickettsial Diseases, Slovak Academy of Sciences, Bratislava, Czechoslovakia, VEDA, pp. 299-305, 1978.

Vaclav R, Ficova M, Prokop P, Betakova T, Microb. Ecol. 61, 245-253, 2011. http://dx.doi.org/10.1007/s00248-010-9736-0

Van Kirk LS, Hayes SF, Heinzen RA, Infect. Immun. 68, 47064713, 2000. http://dx.doi.org/10.1128/IAI.68.8.47064713.2000

Vestris G, Rolain JM, Fournier PE, Birg ML, Enea M, Patrice JY, Raoult D, Ann. N. Y. Acad. Sci. 990, 371-374, 2003. http:// dx.doi.org/10.1111/j.1749-6632.2003.tb07394.x

Vitorino L, Chelo IM, Bacellar F, Ze-Ze L, Microbiology. 153, 160-168, 2007a. http://dx.doi.org/10.1099/mic.0.2006/001149-0

Vitorino L, De SR, Bacellar F, Ze-Ze L, Vector Borne Zoonotic Dis. 7, 217-220, 2007b. http://dx.doi.org/10.1089/ vbz.2006.0603

Walker DH, Clin. Infect. Dis. 45 Suppl 1, S39-S44, 2007. http:// dx.doi.org/10.1086/518145

Walker DH, Vaccine. 27, Suppl 4, D52-D55, 2009. http://dx.doi. org/10.1016/j.vaccine.2009.07.045

Walker DH, Feng HM, Popov VL, Am. J. Trop. Med. Hyg. 65, 936-942, 2001.

Walker DH, Ismail N, Nat. Rev. Microbiol. 6, 375-386, 2008. http:// dx.doi.org/10.1038/nrmicro1866 
Walker DH, Yu XJ, Ann. N. Y. Acad. Sci. 1063, 13-25, 2005 http:// dx.doi.org/10.1196/annals.1355.003

Walter G, Botelho-Nevers E, Socolovschi C, Raoult D, Parola P, Am. J. Trop. Med. Hyg. 86, 1049-1053, 2012. http://dx.doi. org/10.4269/ajtmh.2012.11-0794

Wang Y, Liu Z, Yang J, Chen Z, Liu J, Li Y, Luo J, Yin H, Emerg. Infect. Dis. 18, 1532-1534, 2012.

Weisburg WG, Dobson ME, Samuel JE, Dasch GA, Mallavia LP, Baca O, Mandelco L, Sechrest JE, Weiss E, Woese CR, J. Bacteriol., 171, 4202-4206, 1989.
Weiss K, In Walker DH, Biology of Rickettsial Diseases, Boca Raton, CRC Press, USA, pp. 1-14, 1988.

Wilson LB, Chowning WM, J. Infect. Dis. 1, 37-57, 1904. http:// dx.doi.org/10.1093/infdis/1.1.31

Winkler HH, Daugherty RM, J. Bacteriol. 160, 76-79, 1984.

Wisseman CL, Jr., Zentralbl. Bakteriol. Orig. 206, 299-313, 1968.

Zahringer U, Adv. Carbohydr. Chem. Biochem. 50, 211-276, 1994. http://dx.doi.org/10.1016/S0065-2318(08)60152-3

Zhu Y, Fournier PE, Eremeeva M, Raoult D, BMC Microbiol. 5, 11, 2005. http://dx.doi.org/10.1186/1471-2180-5-11 